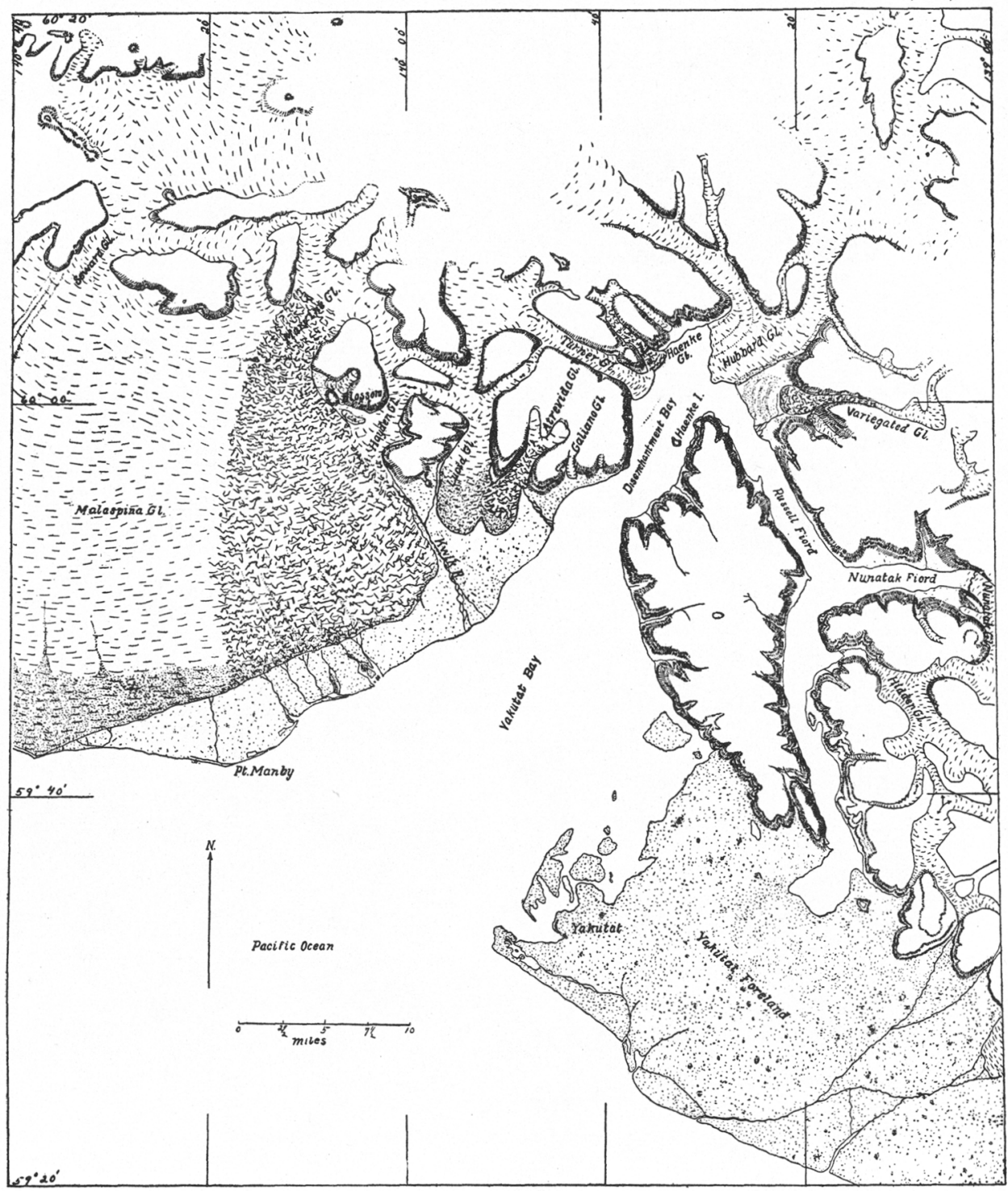

SKETCH MAP OF THE GLACIERS OF THE YAKUTAT BAY REGION

Based on the Alaska Boundary Tribunal map. The newly erevassed glacier is indicated by broken lines 


\title{
RECENT ADVANCE OF GLACIERS IN THE YAKUTAT BAY REGION, ALASKA*
}

\author{
BY RALPH S. TARR
}

(Read before the Society December 28, 1906)

\section{CONTENTS}

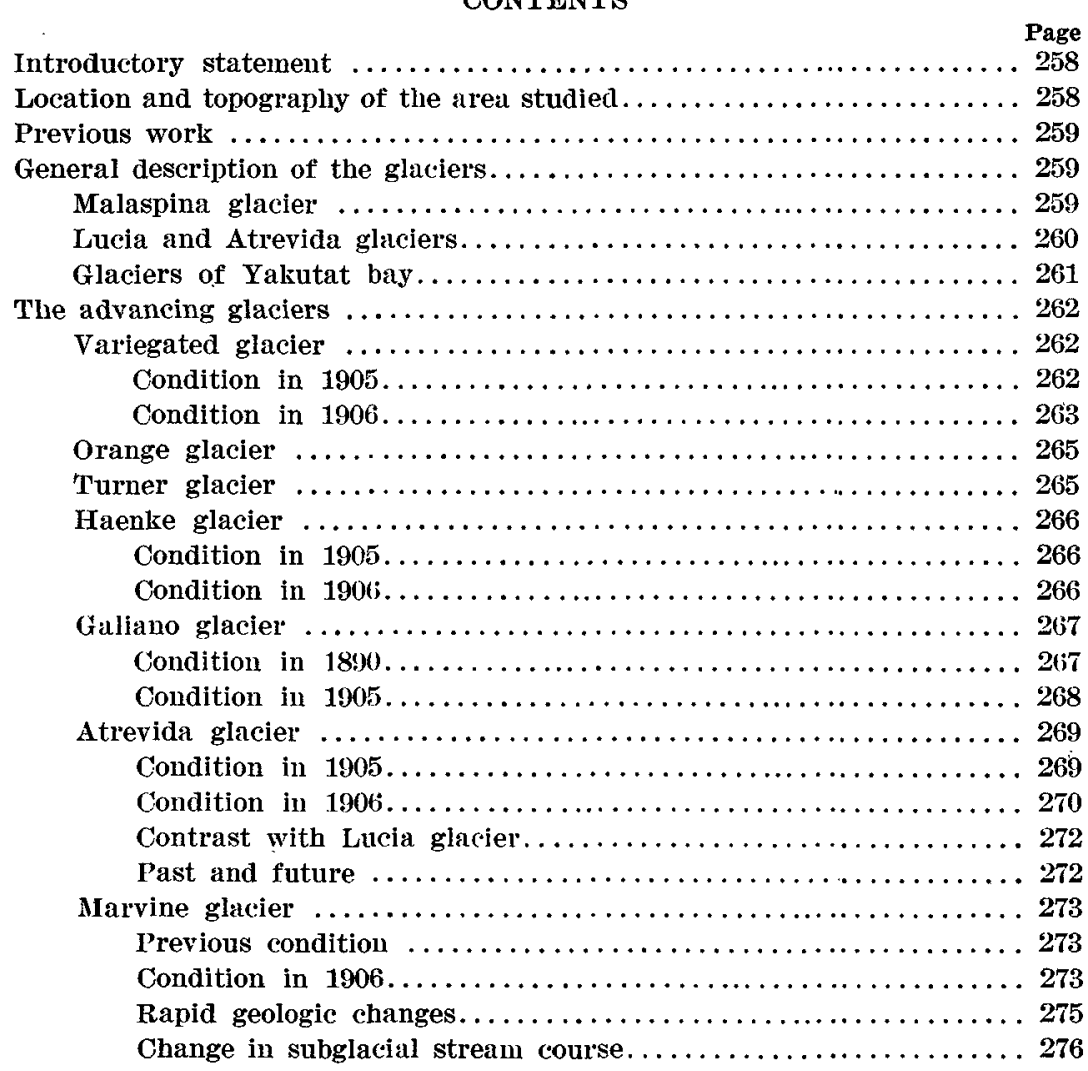

* Published by permission of the Director of the United States Geological Survey. The work on which this paper is based was done in the summers of 1905 and 1906 . I take this occasion to acknowledge the valuable assistance rendered in these two expeditions by my scientific associates, Messrs Lawrence Martin and $B$. S. Butler in 1905, and Messrs B. S. Butler, J. L. Rich, O. Von Engeln, and R. R. Powers in 1906.

Manuscript received by the Seeretary of the Society March 4, 1907. 
Page

Other tributaries to Malaspina glacier................ 277

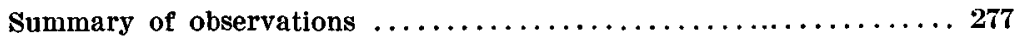

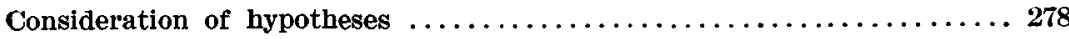

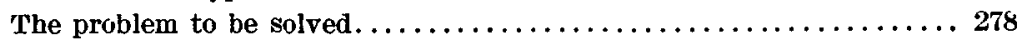

Hypothesis of climatic causes...................... 279

Hypothesis of possible uplift. ...................... 279

Hypothesis of change of grade..................... 279

Hypothesis of breaking by earthquake shocks............. 280

Hypothesis of snow supply resulting from earthquake shaking. . . 280

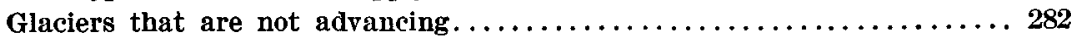

Consideration of the future condition $\ldots \ldots \ldots \ldots \ldots \ldots \ldots \ldots \ldots \ldots . \ldots \ldots$

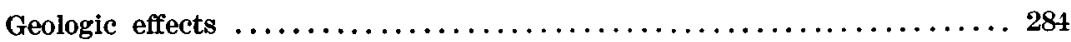

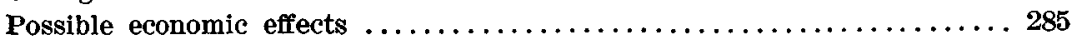

Conclusion $\ldots \ldots \ldots \ldots \ldots \ldots \ldots \ldots \ldots \ldots \ldots \ldots \ldots \ldots \ldots \ldots \ldots \ldots \ldots \ldots \ldots$

\section{INTRODUCTORY STATEMENI}

Since its discovery, the Malaspina glacier has been in a nearly stagnant condition around most of its periphery. As a result of ablation, in this outer portion of the glacier, there has developed a fringe of moraineveneered ice, parts of which support forest growth. Back of this morainic fringe the ice plateau has been so smooth as to permit easy sledging in all directions by the several parties (the last in 1897) which have crossed it on their way to mount Saint Elias. Such was apparently its condition even as late as the summer of 1905 ; but in 1906 that part of the Malaspina glacier which borders Yakutat bay was transformed to a sea of crevasses, across which travel was utterly impossible. This crevassing has been caused by a great forward thrust, which has not only broken the ice surface, but has also pushed forward the glacier margin, and in the summer of 1906 was still pushing it forward.

The evidence is clear that the many smaller glaciers of the Yakutat Bay region were in a condition of general recession up till 1905 ; but between August, 1905, and June, 1906, three of them have undergone a remarkable advance, accompanied by profound crevassing. It is the purpose of this paper to describe these changes and to offer an interpretation of them.

\section{Location and Topography of the AREa studied}

Yakutat bay is an indentation in an otherwise straight coastline about midway between Cross sound and Controller bay. Malaspina glacier bor- 
ders the western shore of the outer bay, being fed by numerous tributaries from mount Saint Elias and neighboring mountains. The outer bay is V-shaped, narrowing toward its head, where it enters between mountain walls as a true fiord known as Disenchantment bay. The entire inlet has the shape of a bent arm, the elbow being at the point where the fiord reaches farthest into the mountains, the part beyond the elbow extending back toward the ocean in a course roughly parallel to the outer bay. The inlet above the elbow is called Russell fiord.

Near the shores of the fiord the mountains reach elevations of from 3,000 to 5,000 feet, but immediately back of these the Saint Elias chain rises to elevations of from 10,000 to 19,000 feet. Situated on a windward coast, these lofty mountains induce heavy precipitation, and are therefore deeply clothed with accumulations of snow at all elevations above two or three thousand feet. It is this great accumulation of snow which causes glaciers to descend nearly all the valleys.

\section{Previous Work}

In 1890 and 1891 Malaspina glacier was studied by Professor Russell, who crossed it along several lines, and from whose deseriptions* we have obtained most of our present knowledge of this interesting ice-sheet. Professor Russell has also briefly described the other glaciers of the Yakutat Bay region. In 1897 both Prince Luigi, Duke of the Abruzzi, and Mr H. C. Bryant crossed Malaspina glacier from outer Yakutat bay to the mountain base. $\nmid$ As a member of the Harriman Alaska expedition Dr G. K. Gilbert studied the glaciers of Yakutat bay in 1899, $\ddagger$ and presented evidence that there had been general recession since the earlier observations of Professor Russell. The photographs and maps of the Alaska Boundary Tribunal clearly show the condition of the glaciers in 1895. The studies of Tarr and Martin in $\mathbf{1 9 0 5}$ prove that the recession of the glaciers continued up to that time. $\$$

\section{GenerdL Description on tile Glaciers MALASPINA GLACIER}

A number of large valley glaciers (see plate 7), descending from the Saint Elias range, spread out at the mountain base to form the broad

* National Geographic Magazine, vol. 3, 1891, pp. 53-203; 13th Annual Report U. S. Geological Survey, 1891-2, pt. 2, Geology, pp. 1-01.

$\dagger \mathrm{Mr}$ Bryant has published no description of his expedition; but the results of the Abruzzi expedition are described in a volume entitled "The ascent of mount Saint Elias, narrated by Filippo de Filippi," 1900.

¥ Halriman Alaska Fxpedition, vol. 3, "Glaciers and Glaciation," 1904, pp. 45-70.

8ull. American Geographical Society, vol, 38, 1906, pp. 145-167. 
piedmont ice plateau known as the Malaspina glacier, which reaches the sea at two points-Icy cape on the west and Sitkagi bluffs on the east. Icebergs are discharged into the ocean from the former, but the latter is merely a moraine-veneered ice-cliff, against the base of which the ocean waves beat.

Each of the tributary glaciers dominates a part of the Malaspina ice plateau. The eastern portion is under the influence of Marvine glacier, which supplies the ice of that part of the Malaspina bordering Yakutat bay. The tributary next west of the Marvine is Seward glacier, and west of this is the Agassiz. East of the Marvine is the much smaller Hayden glacier, which, although completely joined to the Malaspina, produces little effect upon its ice supply, excepting in a very narrow strip along the eastern margin.

A bay in the ice is formed on the lee, or southern, side of the mountains where the Marvine and Hayden glaciers unite, and in this ice-free area a small hill rises, to which Russell applied the name Blossom island. A good-sized stream, supplied by the melting along the margin of the Marvine and several smaller glaciers, traverses this area, expanding into a lake, then escaping beneath Hayden glacier through a subglacial tunnel about 5 miles in length. On emerging from its tunnel, on the eastern margin of Malaspina glacier, this stream is known as Kwik river-a great, rushing, glacial torrent which flows to Yakutat bay in a course roughly parallel to the eastern margin of the Malaspina.

On his way to mount Saint Elias in 1890, Professor Russell crossed Hayden glacier, went across Blossom island, then traversed Marvine glacier. So far as known, his is the only expedition which has previously visited this portion of Malaspina glacier. In $1905 \mathrm{I}$ did not reach this region, but we had clear views of it from neighboring mountains, and two of my party, Messrs Martin and Butler, looked down on it from the slopes on the western side of the Floral hills directly above Hayden glacier. Professor Russell found Marvine glacier easy to cross in $\mathbf{1 8 9 0 .}$ and from our views of 1905 we are convinced that there would then have been no difficulty in crossing this part of Malaspina glacier; but in 1906, from far up the mountain valley north of Blossom island down to the very margin on the shores of Yakutat bay, a distance of not less than 15 miles, that part of the Malaspina dominated by Marvine glacier was so crevassed as to be utterly impassable.

\section{LUCIA AND ATREVIDA GLACIERS}

Lucia glacier lies just east of the Hayden, and adjoining the Lucia on the east is Atrevida glacier. In their lower portion these two glaciers 



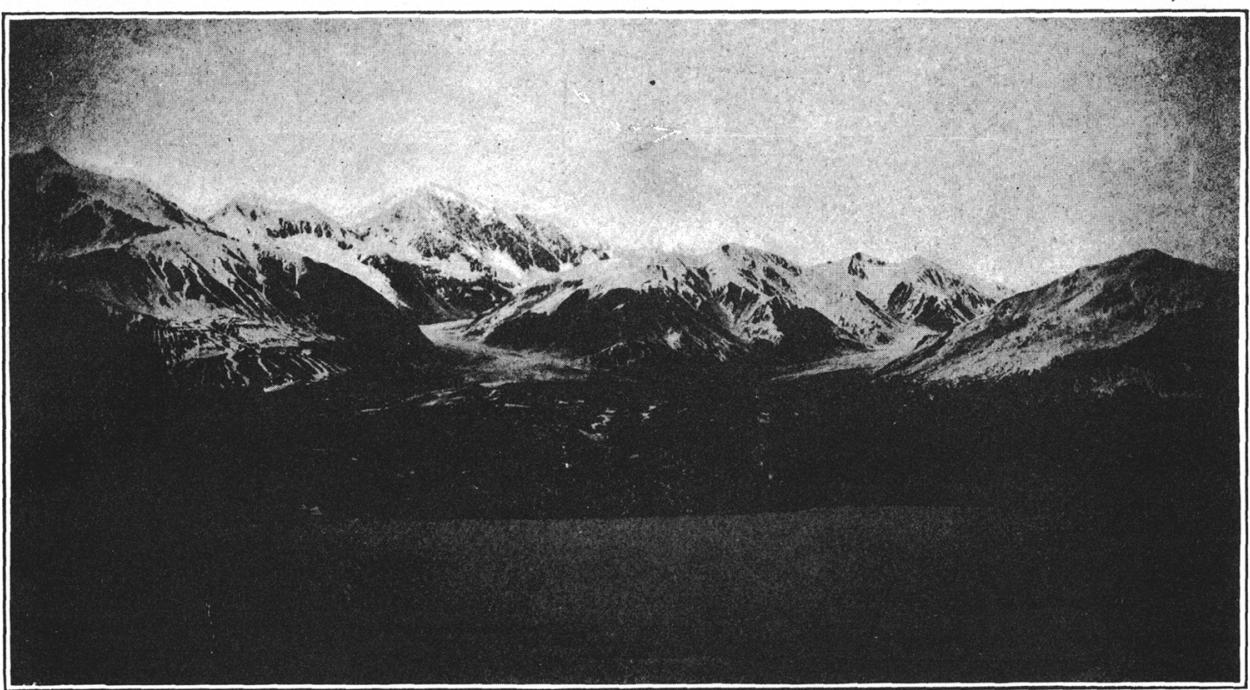

Figure 1.-Variegated Glacier, June 22, 1899

Showing winding course, smooth surface, and moraine-covered terminal portion. Essentially as in 1905. Orange glacier on right. Photograph by G. K. Gilbert

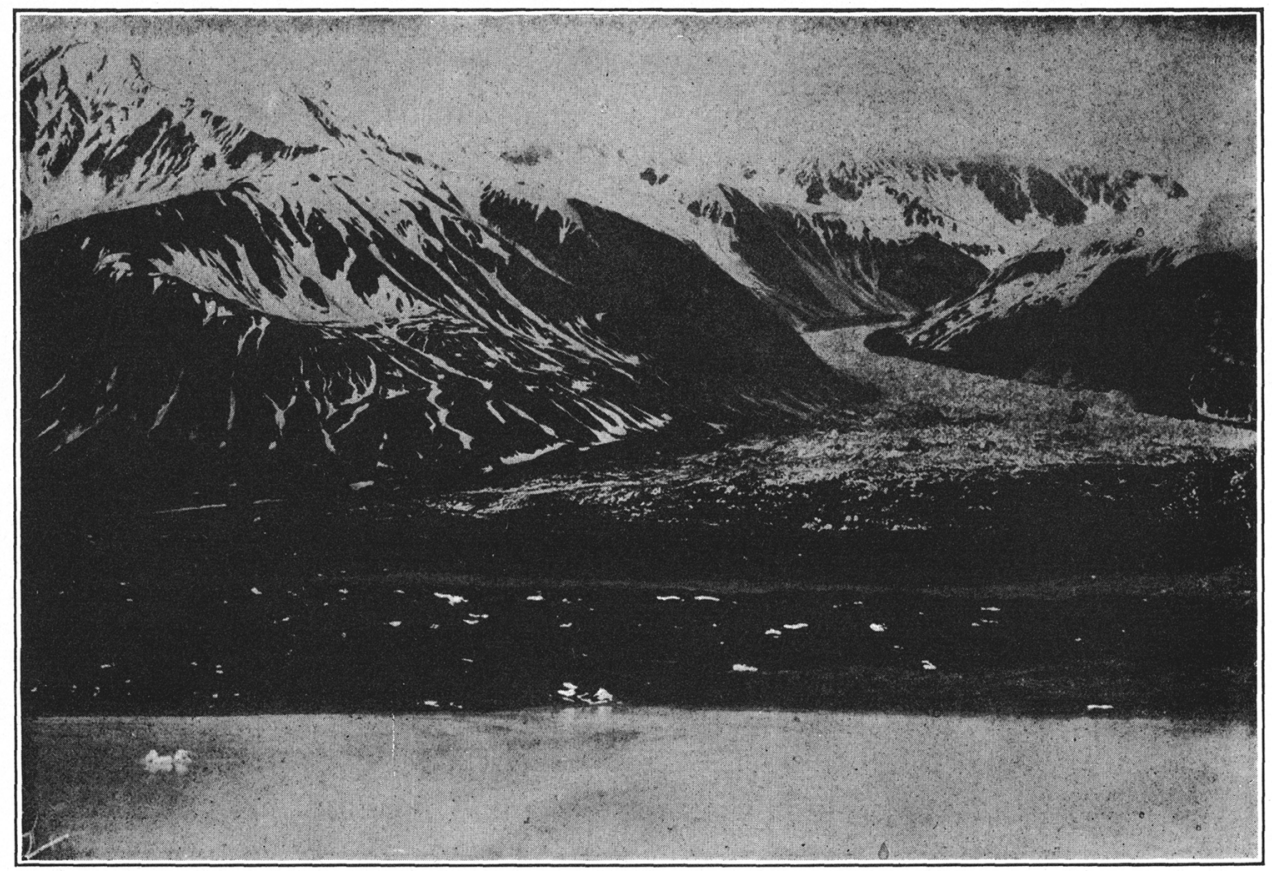

Figure 2. - Long-focus PiCture from same Site as Figure 1

Note crevassed condition dow'n to interior flat. Photograph by O. Von Engeln, July 3, 1906 
coalesce and their terminus extends to within $11 / 2$ or 2 miles of Malaspina glacier, to which they were formerly tributary. At present the alluvial fan of Kwik river separates these glaciers from the Malaspina. In 1905 the lower portions of both Atrevida and Lucia glaciers were essentially stagnant, and from well within their mountain valleys to their terminus were covered with broad wastes of moraine. The outermost portion of the moraine-covered ice was clothed in a dense thicket of mature alder, indicating almost complete stagnation in that part of the glacier.

Russell crossed both these glaciers in 1890. In 1905 I walked freely over Atrevida glacier in company with Messrs Martin and Butler, and later they crossed Atrevida and Lucia glaciers on their way to Floral hills; but in 1906 crevassing, due to a rapid forward movement, had completely altered the condition of Atrevida glacier. The Lucia, on the other hand, was in no way different from its condition in 1905, at least along and near the route followed by Messrs Martin and Butler.

\section{GLACIRRS OF YAKUTAT BAY}

Galiano glacier (plates $;$ and 13), the next one east of the Atrevida, was the same in the two summers; but there is evidence of distinct change between 1890 and 1905 .

Three tidal glaciers discharge into Yakutat Bay inlet. The outermost of these, Turner glacier, underwent no notable change in the interval between 1905 and 1906 ; but a small unnamed glacier just north of it, which I shall call Haenke glacier (plates 11 and 12), has advanced into the sea, uniting with the ice-cliff of the Turner. Hubbard glacier was essentially the same in 1906 as in 1905 ; but the much smaller Variegated glacier (plates 8-10), just east of it, shows profound change. The tidal Nunatak glacier, at the head of Nunatak fiord, continued to recede between 1905 and 1906, as it had been doing at such a remarkable rate between 1891 and 1905.* Another large glacier, the Hidden, whose terminus is on an alluvial fan back from the sea, shows no notable change. There are many smaller glaciers in the bay, and in none of these was any evidence of recent advance discovered.

This brief description makes it clear that four of the many glaciers in the Yakutat Bay region have been subjected to some influence which has caused a very remarkable change in condition in the short interval of ten months between August, 1905, and July, 1906. The nature of this

*Tarr and Martin : Bull. American Geographical Society, vol. 38, 1906, p. 154. 
change will now be more definitely stated for each of the glaciers concerned.

\section{The advancing Glaciers}

\section{VARIFGATED GLACIER}

Condition in 1905.-Variegated glacier (plates 8-10), having its source far back in the mountains, descends in a serpentine course through a valley greatly steepened by glacial erosion (plate 8 , figure 2). On emerging from its mountain valley, the glacier expands into a broad, bulb-shaped area which extends westward until it coalesces with Hubbard glacier, and southwestward almost to the sea.

In August, 1905, this glacier was studied with some care, especially in its bulb-shaped expansion outside of the mountain front, which presented some interesting morainic phenomena. We walked freely over the bulb-shaped terminus and ascended the valley glacier to a point 6 miles or more from the sea. At that time all parts of the glacier visited were easily traversed and possessed no areas of marked crevassing. In the middle of August the snowline on the glacier was at an elevation of approximately 2,200 feet. At and above snowline there was some crevassing, but not enough to impede travel as far up as we went. In this upper portion numerous small tributary glaciers descended by steep grades from hanging valleys.

Below snowline the glacier surface was rapidly melting, and toward the end of the mountain valley it was littered with angular rock fragments. Everywhere the surface was so smooth that one could travel in a straight course over it with almost no detours on account of crevasses (plate 9, figure 1). The slope of the valley portion of the glacier varied from 7 to 10 degrees, but flattened decidedly near the end of the mountain valley, where in places the grade was even reversed.

On emerging from this mountain valley Variegated glacier expanded abruptly and, through ablation, became covered with an almost continuous sheet of moraine. This morainic veneer varied in thickness, causing a succession of ridges and intermediate depressions arranged concentrically (plate 9). These concentric ridges, which roughly paralleled the bulb-shape of the expanded ice-foot, consisted of rocks of various kinds and colors, giving rise to a remarkable series of crescentic moraines whose characteristics we studied with some care. The outer portion of the expanded ice-foot, near the sea, was so stagnant and so deeply covered by moraine that scattered willows and alders were growing on it, and the 


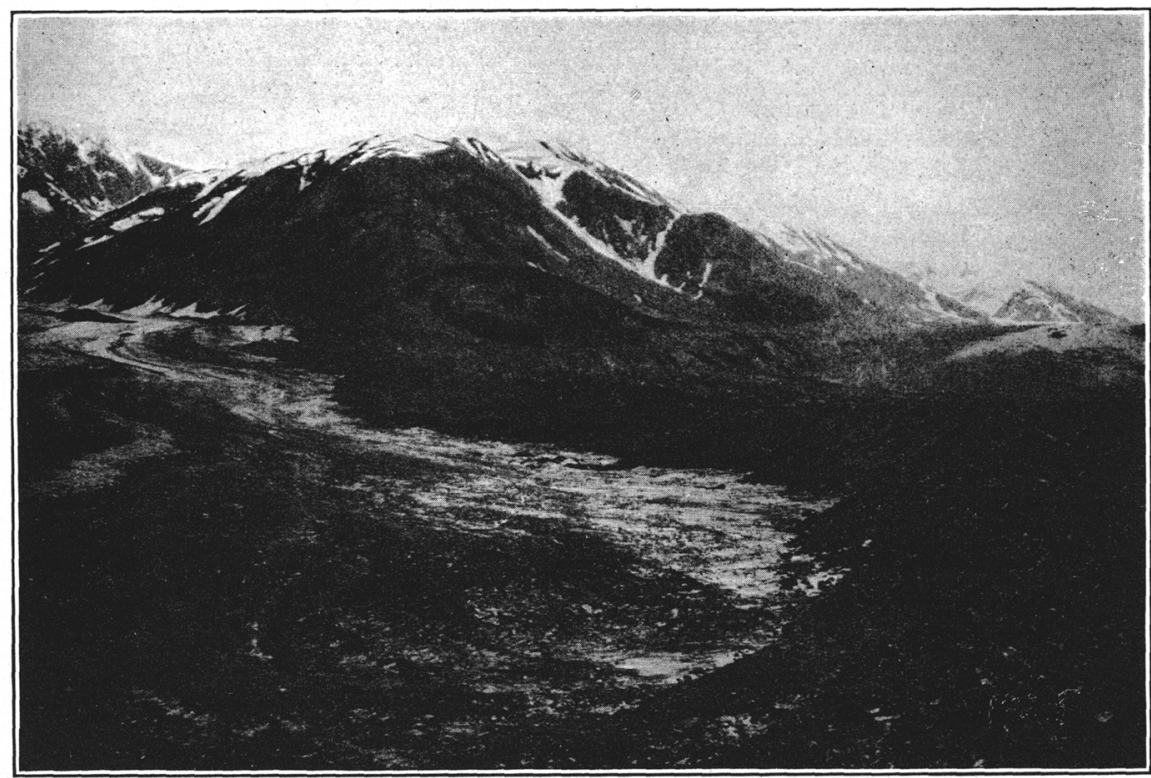

Figure 1.-Inner Edge of moraine-covered Variegated Glacier

Transformed in 1906 to sea of crevasses. Orange glacier on left. Photograph by Lawrence Martin, August 8, 1905

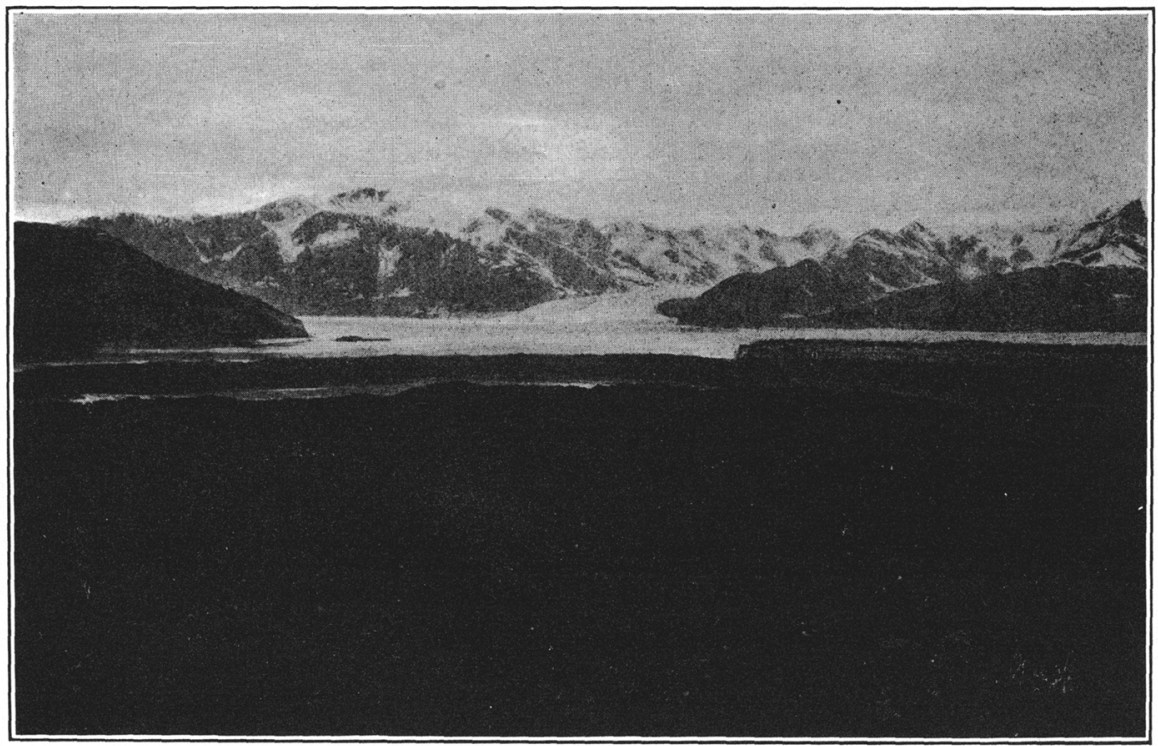

Figure 2.-Moraine-covered Portion of Variegated Glacier

Transformed in 1906 to crevassed condition shown in plate 10, figure 2. Photograph by Lawrence Martin, August 8, 1905

VIEWS OF MORAINE-COVERED OUTER VARIEGATED GLACIER, 1905 

underlying ice was only occasionally revealed. It was this stagnant outer portion which reached up to and coalesced with Hubbard glacier.

Within this outer stagnant area was a long crescent-shaped depression (plate 10) underlaid by ice, into which two glacial streams, emerging from the moraine-covered inner portion of Variegated glacier, poured their sediment, building up a broad flat through the coalescing of the alluvial fans. On emerging from the ice the larger, or southeastern, stream entered a canyon in the granite bed rock, and after a short course, interrupted by a notable waterfall, emerged from it at the head of its alluvial fan (plate 10, figure 1 ).

Inside of and concentric with this interior alluvial flat, the morainecovered ice rose steeply in a succession of concentric ridges of variously colored moraines-red, orange, and purple. This inner portion of the glacier, although almost completely covered with moraine (plate 9, figure 2), was evidently more active than that part which lay outside the interior flat. Vegetation was represented only by occasional annual plants, and now and then by a willow a year or two old. The moraine was so thin that ice was frequently visible and could almost always be reached by thrusting the ice-ax into the moraine. There was no crevassing, and it was evident that this part of the glacier, like the portion within the mountain valley, was rapidly wasting. The inner edge of this morainecovered area, lying almost at the very mouth of the mountain valley, was crescentic in outline and rose steeply and abruptly above the rapidly melting clear ice of the valley glacier (plate 9 , figure 1 ).*

Condition in 1906.--The above description applies to Variegated glacier in the middle of August, 1905. When we again saw it, late in June, 1906, it was absolutely altered (compare figures 1 and 2 , plate 8 ). The area of stagnant ice outside of the interior flat was unchanged. The flat itself was also essentially as it was in 1905, though slightly smaller; but all the ice to the northeast of the flat was broken into an impassable condition (plate 8, figure 2). In a period of ten months this glacier was altered from one over which we easily passed, making a journey of over 12 miles in a single day, $\nmid$ to one whose crevassed margin, even, we found it impossible to ascend without the laborious work of cutting steps in the ice.

Not only was the moraine-covered expansion, just outside of the mountain valley, broken into a labyrinth of crevasses, but this condition ex-

\footnotetext{
* For further description and llistration of this glacier, see Tarr and Martin, Bull. American Geographical Society, vol. 38, 1906, pp. 147-149.

$\dagger$ This refers merely to the distance in a straight line, for we made many side trips during this day.
} 
tended at least as far up the valley as we had gone the previous summer, and from one side of the valley to the other. By the crevassing, the concentric moraines northeast of the interior flat were completely destroyed, the ridges being replaced by a uniform maze of jagged ice pinnacles. Some of the moraine still clung to the flatter portions of the broken ice, but most of it had tumbled into the crevasses. In consequence of these changes a large measure of clear ice appeared where, in 1905, only moraine was seen when viewed from a distance. Thus the appearance of the glacier was as totally altered as its condition.

In addition to this breaking, there has been a decided thickening of the lower portion of the advancing glacier, so that it now rises between 200 and 300 feet higher than it did in $\mathbf{1 9 0 5}$ (compare figures 1 and 2, plate 10). The margin has also advanced seaward and encroached somewhat on the interior flat; but the advance has not disturbed the ice platform of the flat, nor of the moraine-covered area outside of it. Exactly how much of an advance there has been can not be stated, since we have no exact basis for measurement, though, so far as could be told from comparison of photographs, it seems to be certainly not less than 200 yards. The forward movement has caused the ice to override and bury the granite gorge which was visible in 1905 (plate 10), and the forward thrust has so completely destroyed the system of subglacial drainage that a stream no longer emerges from this part of the glacier. Instead, a large stream now issues from the eastern side of the glacier, descending through a marginal channel which in 1905 carried little, if any, water from Variegated glacier.

By this transfer in position of the glacial stream the rapid building up of deposits in the interior flat has stopped, and the stream emerging from it is greatly diminished in volume. On the other hand, a stream which in 1905 carried waters mainly from Orange glacier is now greatly increased in volume and rushes as a violent torrent through a marginal channel cut in the granite more than a quarter of a mile from its course in the previous summer. On emerging from this canyon the stream spreads out over a broad alluvial fan in a series of distributaries.

This fan, which is built out into Russell fiord, is very large, and in 1905 attracted our attention especially because glacial waters no longer occupied the eastern portion, on which, instead, there was a dense alder growth, with the individual bushes at least twenty-five years old. We interpreted this condition to be the result either of a diminution in volume of the glacial waters or of a transfer in their point of emergence. We little suspected, however, that in ten months this part of the fan 


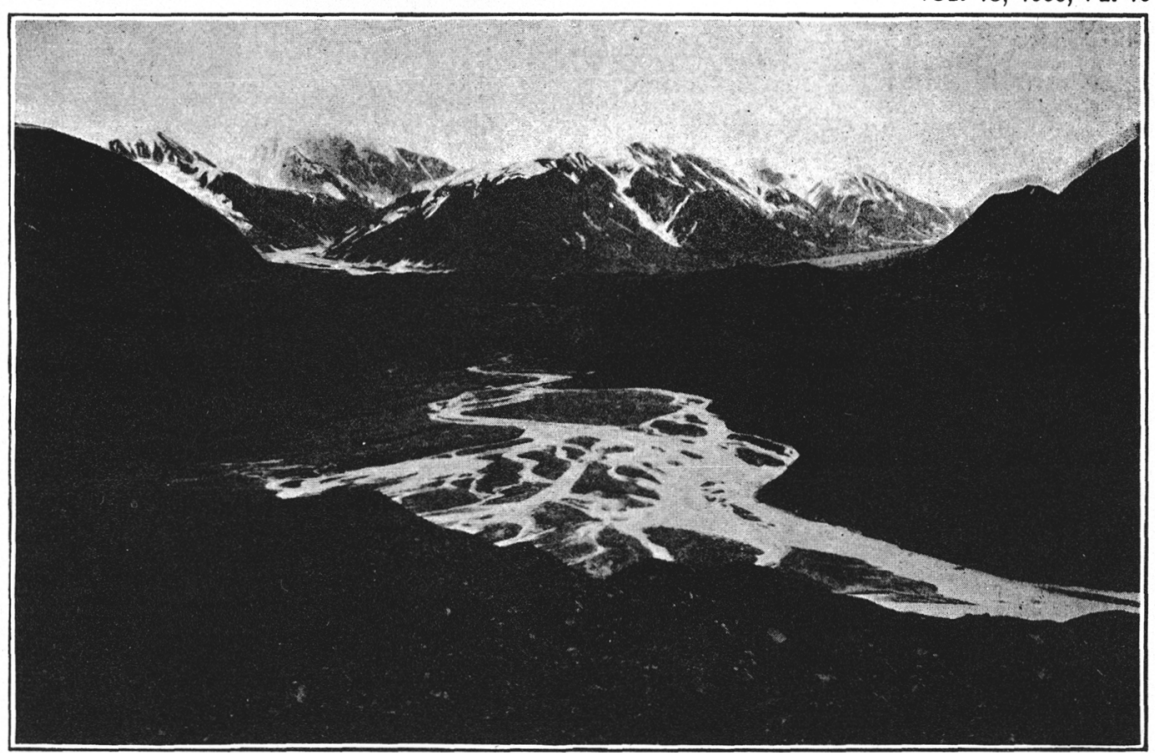

Figure 1.-INTERior Flat and inner moraine-COVered ICe From OUter moraineCOVERED VARIEGATED GLACIER

Photograph by Lawrence Martin, August 8, 1905

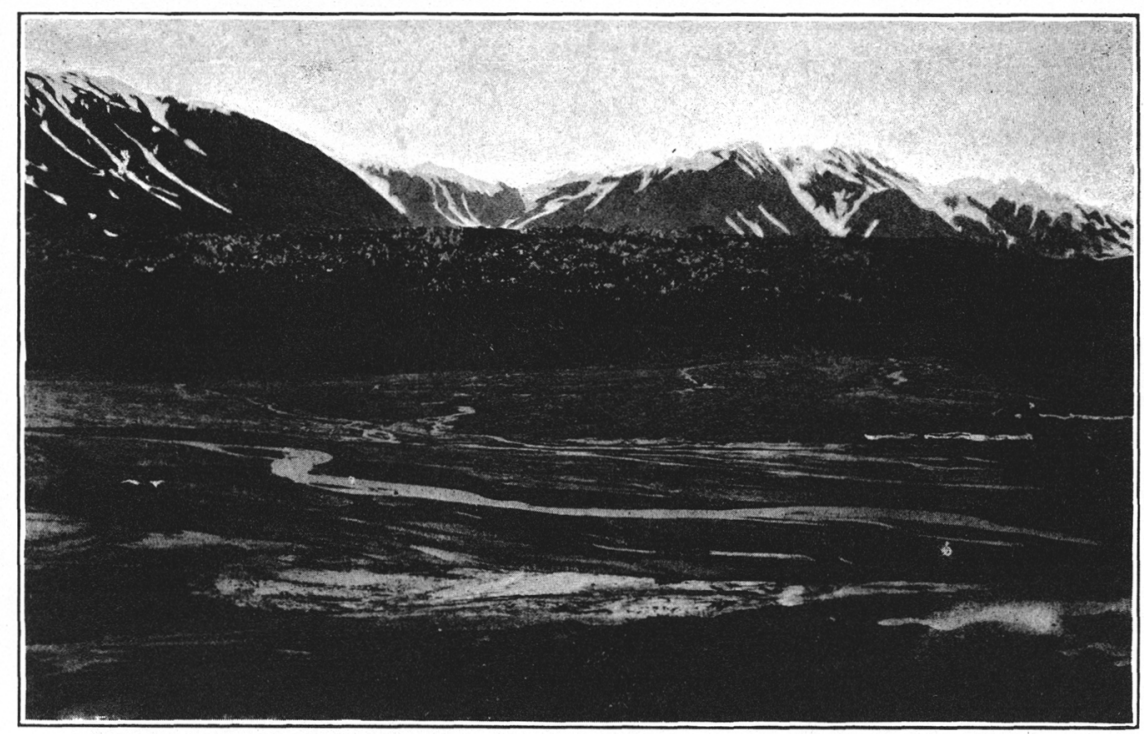

Figure 2.-Long-focus I'ictere of interior Flat, August 17, 1906 Compare with Figure 1 


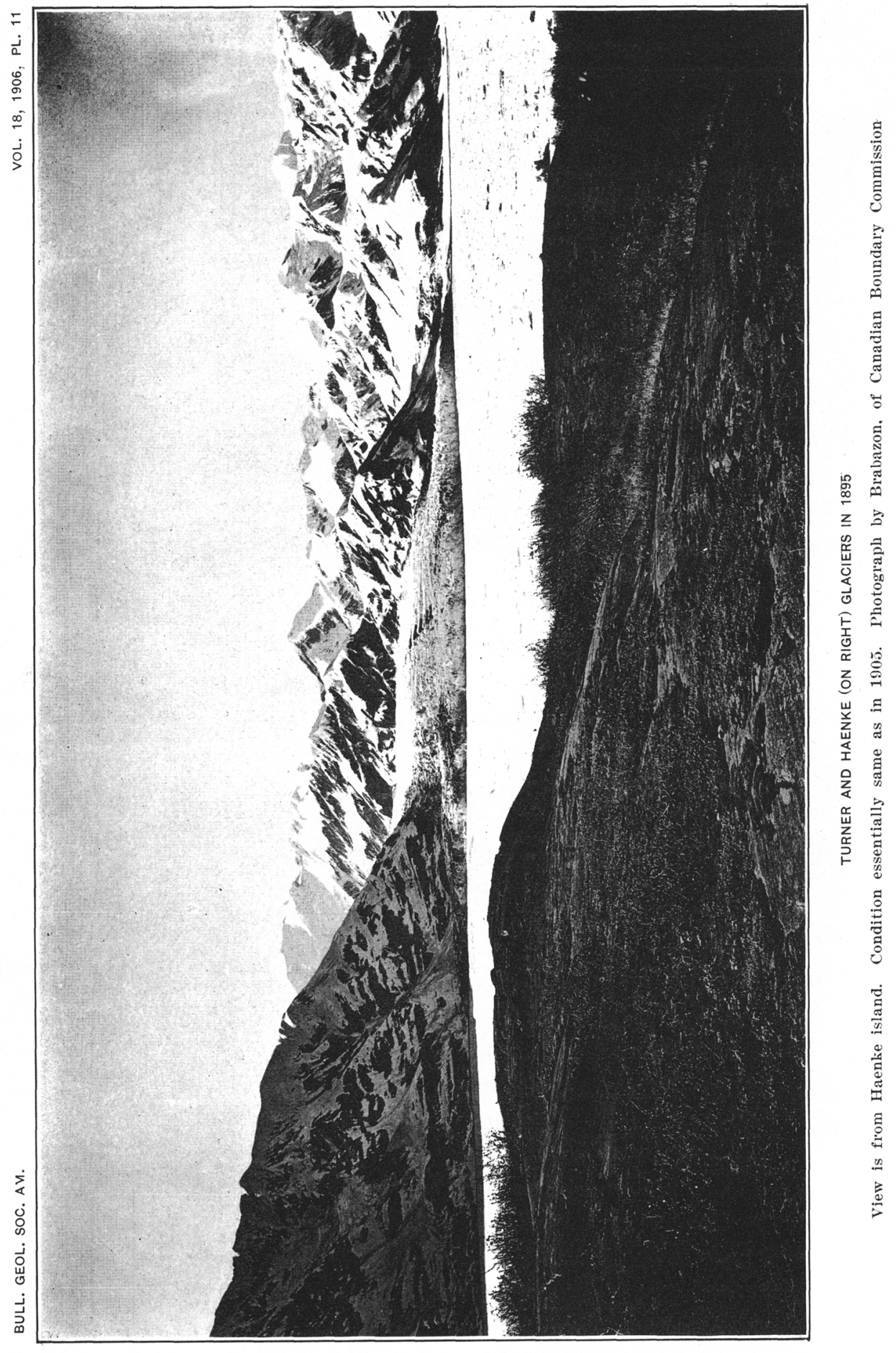


would again be occupied after an interval of freedom from deposit of over a quarter of a century.

By this change the heavily sediment-laden glacial stream is now coursing through the alder thicket in a multitude of branches which are rapidly killing and burying the bushes. That this change occurred late in the spring or early in the summer of 1906 is proved by the fact that all the alders are in full leaf. That the complete destruction of the alder thicket is imminent is evident from the fact that the roots of the plants are bathed in glacial waters, while the gravel deposit is rapidly rising above them. The summer of 1906 is probably the last season of life for these plants.

\section{ORANGE GLACIER}

East of the expanded ice-foot of Variegated glacier there is another glacier which heads on a low, flat divide from which the ice descends eastward toward Nunatak fiord and westward toward Variegated glacier. This, which I now call the Orange glacier (plates 8 and 9), ${ }^{*}$ because of the presence on it of a pronounced orange-colored medial moraine, is a smooth, flat glacier with gentle grade and, so far as we could see, with no pronounced tributaries, its supply coming mainly from snowfall and snowslides in the flat divide area. Since the inclosing mountains are not lofty and the tributaries few and small, this glacier differs widely from the neighboring Variegated glacier. Although we did not go out on Orange glacier in 1905, we saw clearly all but its terminus, and are convinced that it was then in essentially the same condition as in 1906, when we made a journey out upon it nearly up to the snow-line.

Thus we have the anomaly of two neighboring glaciers, both of which were essentially uncrevassed and easily traversed in August, 1905, but one of which has so changed as to become impassable in a period of ten months, while the other shows no noticeable change. In fact, one of them, Variegated glacier, is so broken that attempts to ascend the margin to a point where we photographed it in $\mathbf{1 9 0 5}$ were completely frustrated.

\section{TURNER GLACIER}

This glacier (plates 11 and 12) flows eastward from mount Cook through a valley more than a mile in width, and on passing ont of its mountain valley expands to about double this width, ending in an ice-

* The name Variegated glacier was extended to this by Tarr and Martin in 1905, on the belief, which we shared with Russell and Gilbert, that it was continuous with the stagnant moraine-covered ice described above; but in 1906 we went out on it and found it almost completely separated from the stagnant fce-foot, which is really a part of the advancing Variegated glacier, as stated above. The name of 1905 is therefore inappropriate and is withdrawn. 
cliff from which icebergs are discharged into Disenchantment bay. It is an actively moving and greatly crevassed glacier, and this has been its condition since first seen by Russell in 1890 .

\section{HAENKE GLACIER}

Condition in 1905.- Not over half a mile north of the Turner there is a small glacier (plate 11), and about three-quarters of a mile farther north another similar one. These two glaciers have never been named. In 1905 they were so nearly alike that a description of one would practically apply to the other. Each descended rather steeply, at an angle of perhaps 15 or 20 degrees, and ended at the head of an alluvial fan about a quarter of a mile from the fiord. The lower mile of their course consisted of what appeared to be essentially stagnant ice, so veneered with black shale fragments as to completely hide the ice when viewed from a distance. Because of this blackness none of our photographs reveal the true glacier character of the lower ends, though it was evident enough to the eye. It is, however, clearly shown in a Boundary Commission photograph taken in 1895 , from which it is evident that the condition was then identical with that in 1905 .

Condition in 1906.-In June, 1906, the northern glacier had advanced somewhat and become slightly crevassed; but the southern, or Haenke glacier, had undergone a wonderful change (plate 12). It had not only advanced over its alluvial fan, but had moved boldly out into the fiord, expanding both to the north and south, in the latter direction coalescing with Turner glacier, and extending the ice-cliff of that glacier fully a mile to the northward. As a result of this forward advance, the front of Haenke glacier had by June, 1906, advanced not less than a mile farther out than it was ten months before.

As in the case of Variegated glacier, this forward rush has broken the ice into a sea of crevasses, from the ice-cliff in the fiord to a point at least as far up the mountain valley as we could see. Unlike Variegated glacier, this breaking of the ice has not been followed by a notable disappearance of the morainic veneer, and therefore its surface is still black with debris. This fact may be due to the recency of the advance, although in all probability it is chiefly the result of the difference in climate between this point and Variegated glacier. Lying as it does between the ice-cliffs of the Turner and Hubbard glaciers, and fronted by a continuous stream of floating ice, the climate of this part of the inlet is decidedly colder than other portions. In fact, in the first week of July snow still remained on the alluvial fan north of Haenke glacier. There 


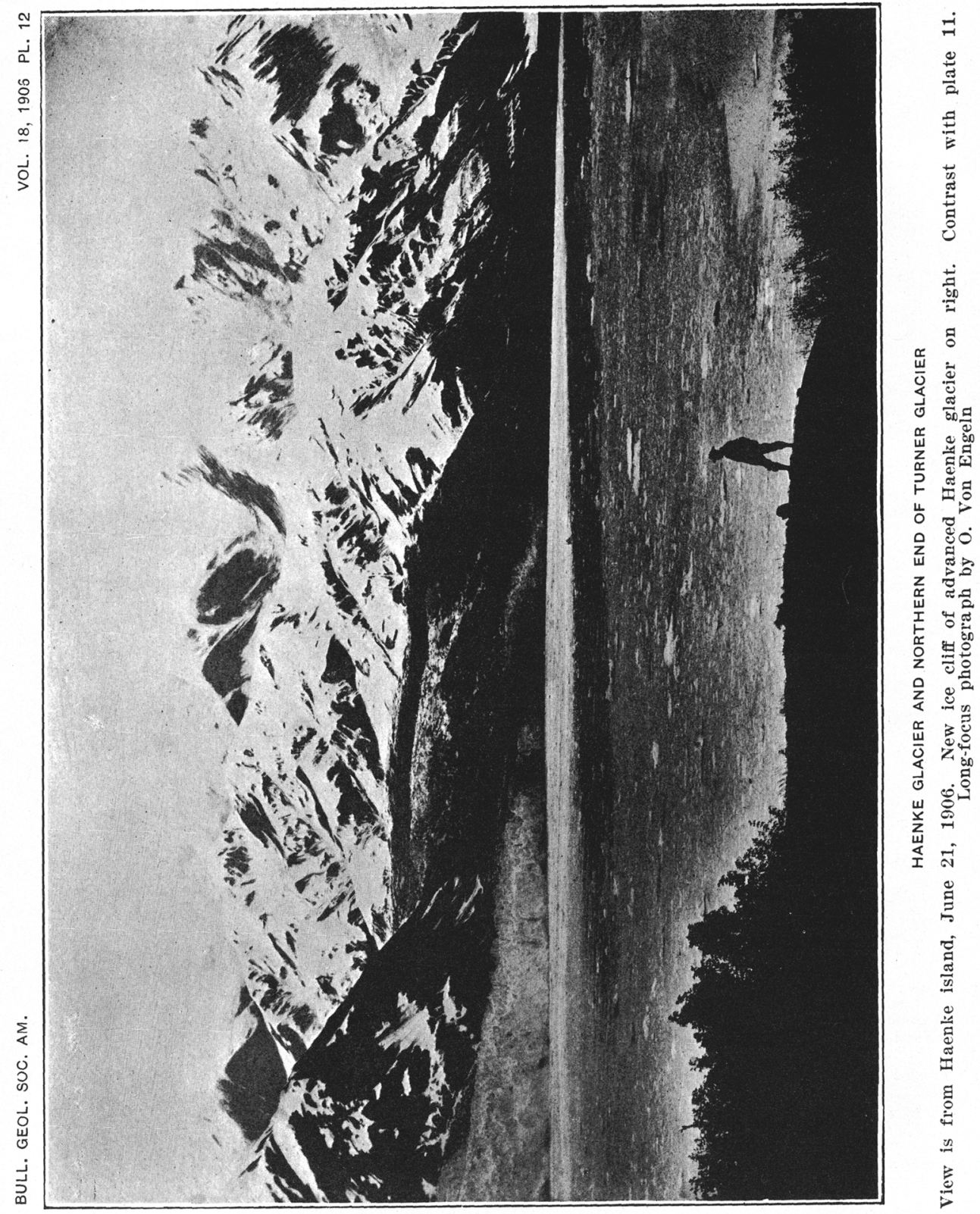




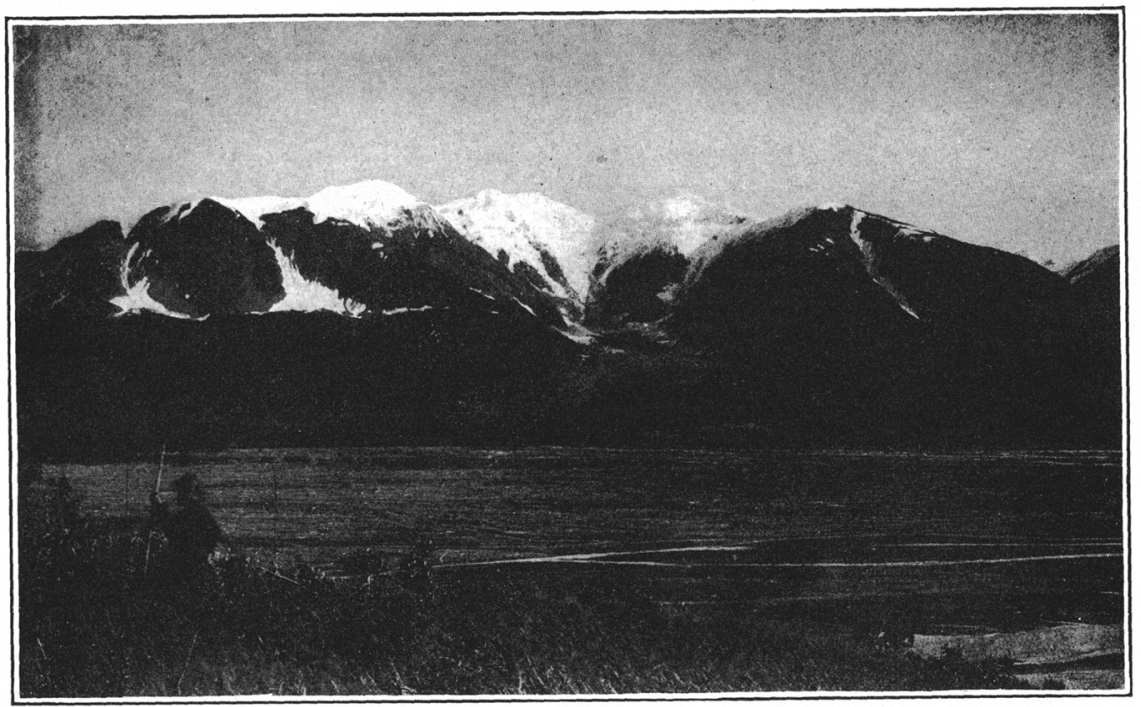

Figure 1.-Galiano Glacier, 1890

Dark part just outside mountain valley is alder growth on glacier. Photograph by I. C. Russell

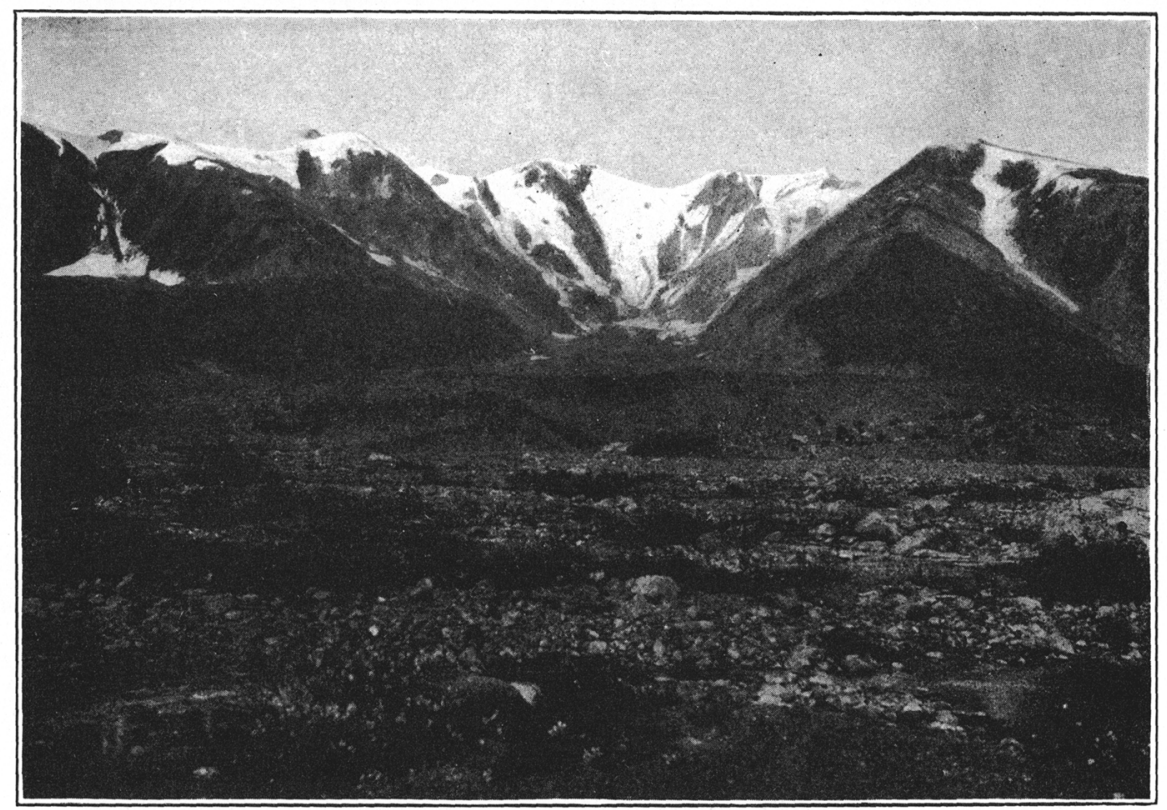

Figure 2.-Galiano Glacier

From near same site as Figure 1, August 21, 1905. Note absence of alder, destruction of alluvial fan, and development of moraine on its site 
has therefore been little opportunity for ablation to lower the morainic debris into the recently formed crevasses of Haenke glacier.

If the advance which has pushed Haenke glacier out into Disenchantment bay should continue, and if the neighboring glaciers should share in it, it seems by no means improbable that the ice-cliff of Turner glacier might be united with that of Hubbard glacier. Such a paroxysmal thrust as has affected this small valley glacier, extended to the much greater Hubbard and Turner glaciers, might even result in again filling Disenchantment bay with glacier ice. This result would surely come about if these two great glaciers should receive a similar impulse proportional to their great size. Even as applied to this small Haenke glacier, the forward movement is astonishing; and although, owing to the uncertainty as to the cause and the nature of its effects, no prediction can be made as to the future, it is certainly within the realm of possibility that the next few years may witness some remarkable changes in the great tidal glaciers of Disenchantment bay.

\section{G.LLIANO GLACIER}

Condition in 1890.--In 1890 Professor Russell camped on the west side of Disenchantment bay, near the end of Galiano glacier (plate 13). He gives the following description of its terminus:*

"To the north of our camp, and about a mile distant, rose a densely wooded hill about 300 feet high, with a curving outline, convex southward. This hill had excited my curiosity on first catching sight of the shore, and I decided to make it my first study. Its position at the mouth of a steep gorge in the hills beyond, down which a small glacier flowed, suggested that it might be an anclent moraine, deposited at a time when the ice-stream advanced farther than at present. My surprise therefore was great when, after forcing my way through the dense thickets, I reached the top of the hill, and found a large kettle-shaped depression, the sides of which were solid walls of ice fifty feet high. This showed at once that the supposed hill was really the extremity of a glacier, long dead and deeply buried beneath forest-covered debris. In the bottom of the kettle-like depression lay a pond of muddy water, and, as the ice-cliffs about the lakelet melted in the warm sunlight, miniature avalanches of ice and stones, mingled with sticks and bushes that had been undermined, frequently rattled down its sides and splashed into the waters below. Further examination revealed the fact that scores of such kettles are scattered over the surface of the buried glacier. This ice-stream is that designated the Galiano glacier on the accompanying map."

The photographs which Professor Russell took of Galiano glacier show clearly that its lower end was then completely covered with alder thicket

* Natlonal Geographie Magazine, vol. 3, 1891, p. 89. 
(plate 13, figure 1). They moreover reveal the fact that there was an extensive alluvial fan southwest of the alder-covered glacier terminus.

Condition in 1905.-On our visit to this region in 1905 we were greatly surprised and puzzled* by the fact that Galiano glacier no longer supported an alder thicket (plate 13, figure 2). On investigation we found much wood scattered over the moraine-covered terminus of the glacier, and even battered stumps in place. We were further puzzled by the fact that the alluvial fan, which shows clearly in Russell's pictures, was no longer present (compare figures 1 and 2 , plate 13). In its place there is much moraine, over certain portions of which wood fragments are scattered (plate 14), as if alder and cottonwood growth had been destroyed. The glacial streams now wind through this moraine in a multitude of channels, and their deposits are rapidly burying the morainic hummocks (plate 14). There is every appearance of having been an upward thrust through an alluvial fan, destroying it, throwing down vegetation wherever it grew, and leaving scattered morainic hummocks in place of the fan. The signs of this disturbance extend over a bulb-shaped area to a distance of 3 or 4 miles from the visible terminus of Galiano glacier.

The explanation of such a remarkable change seemed so difficult to us that in our preliminary report we did not discuss it fully. Nevertheless we were even then forced to the conclusion that between 1890 and 1905 there must have been a forward thrust of Galiano glacier which broke up a bulb-shaped expansion of the glacier that was buried beneath alluvial fan deposits of the glacial streams. We searched carefully for evidence of buried ice in this area, but found no definite proof of it, although from the larger areas of morainic hummocks there was far more water emerging, and with lower temperature, than could be accounted for by the normal run-off of rainfall. Moreover, there were numerous water-filled pits in the moraine, proving recent sinking, but none in which we could be positive that the settling was still in progress.

In the light of the observations of $1906 \mathrm{I}$ am convinced that these changes are to be correlated with the changes which were observed in the other glaciers described in this paper, and that a few years ago the Galiano glacier was subjected to a forward thrust similar to that now affecting Variegated, Haenke, and Atrevida glaciers. The effect of this thrust has now died out and the glacier is returning to its normal condition, although as yet the alder has not again taken root on the moraine and the alluvial fans have not yet again buried the moraine of the out-

* Tarr and Martin : Bull. American Geographical Society, vol. 38, 1906, p. 152. 

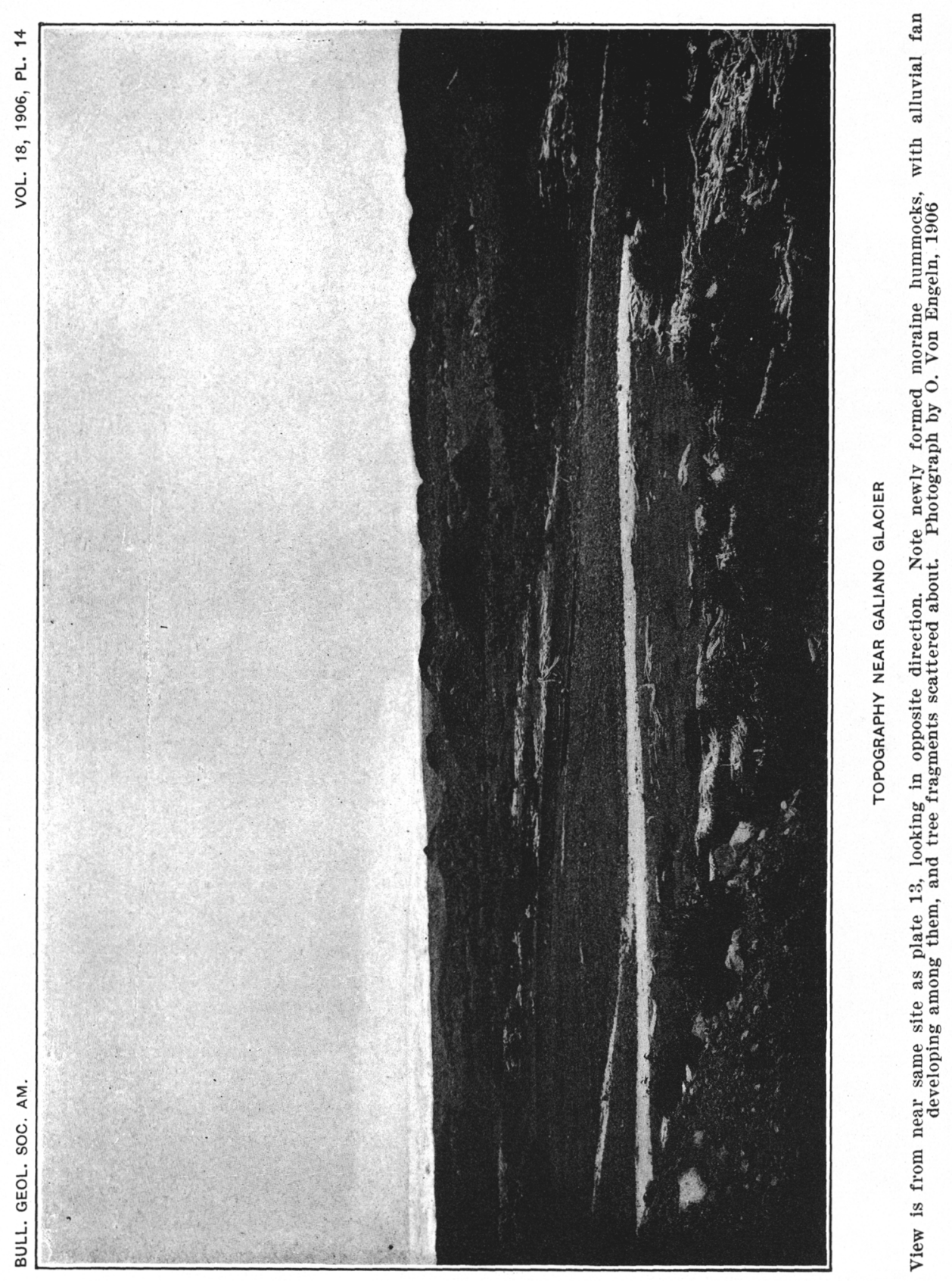


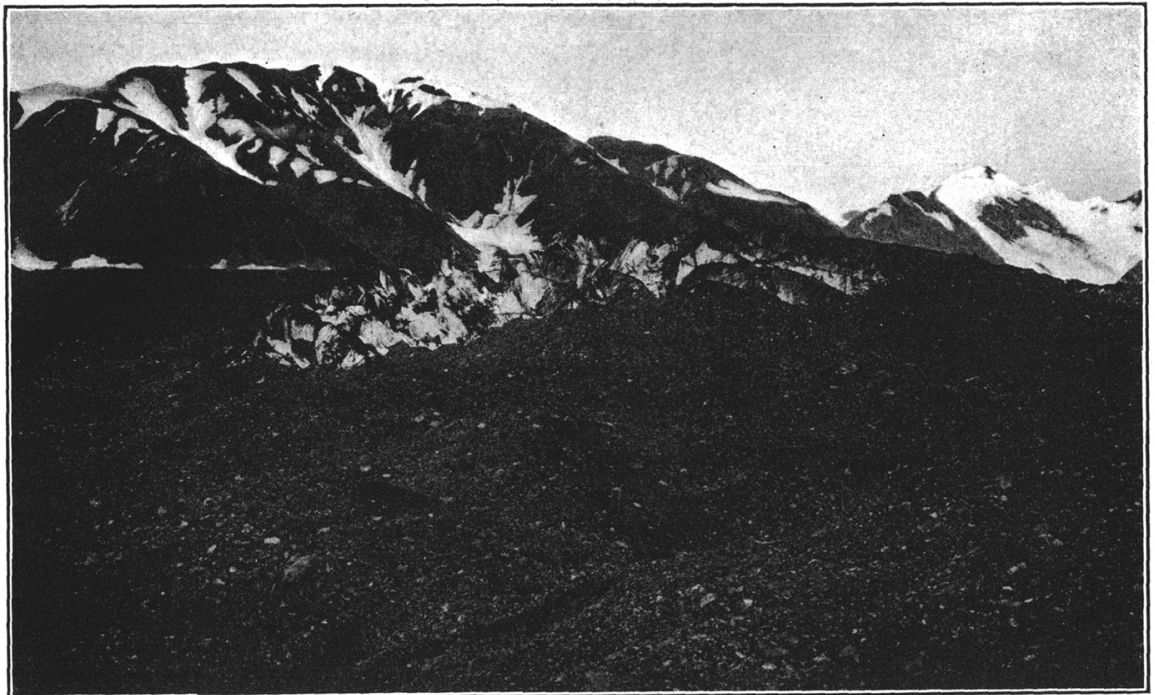

Figure 1.-Morainic Waste on Atrevida Glacifr with a single crivassed Area

View looking north from near middle of glacier. Photograph by Lawrence Martin, August

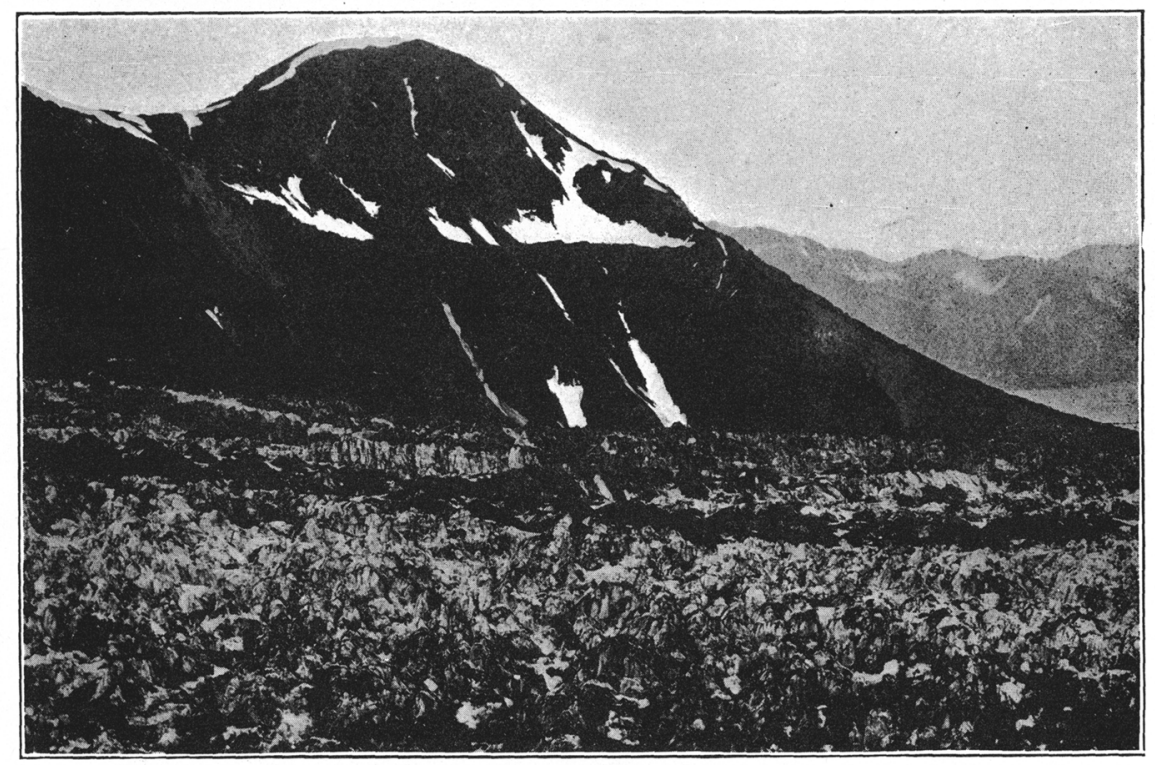

Figure 2.-Surface of Atrevida Glacier

Looking south from west margin. Site of figure 1 about in middle of picture. Photograph (long focus) by 0 . Von Engeln, August 2, 1906 
lying, bulb-shaped terminus. If this is the true interpretation of the phenomenon, as it seems to be, we may expect that the other advancing glaciers will also soon cease their forward movement and return to their former state of stagnation.

There is a special reason why Galiano glacier might well have been early affected by the cause which is pushing these glaciers forward. It occupies a valley with steeply rising walls, from which the snow might easily be shaken down, and is so short that the effect of such an unusual accession of supply would quickly be transferred to the outer margin of the glacier (plate 13). A comparison of Russell's photographs with the conditions of 1905 shows clearly that there has actually been a great downfalling of snow and ice since his photograph was taken (compare figures 1 and 2, plate 13). Large areas of the steeply sloping mountains which were then covered with snow and ice are now bare rock.

\section{ATREVIDA GLACIER}

Condition in 1905.-The Atrevida glacier (plates 15-19) descends through a broad, steep-sided mountain valley, and on its emergence spreads out in a fan-shaped piedmont terminus. Where it emerges from its mountain valley it is somewhat more than a mile in width, but outside of the mountains it attains a width of not less than 3 miles.

In August, 1905, the lower part of this glacier was covered with a broad sheet of moraine, almost completely obscuring the ice, and extending from well within the mountain valley to the terminus of the glacier. On the outer portion of this moraine-covered ice there was a dense alder thicket, so obscuring the moraine that it was impossible from distant views to tell where the glacier ended.

At this time it was easily possible to travel over any part of the glacier excepting the alder-covered portion, where the dense growth of vegetation obstructed the way. With my party I looked down on the glacier from the mountains which rise directly above its eastern margin; later we made a trip out to the middle of the glacier; and still later Messrs Martin and Butler crossed it on their way to Blossom island, following the route which Russell took in 1890. At that time a mature spruce forest extended close up to the moraine-covered eastern edge of the ice, and a stream emerged from the extreme eastern margin through a tunnel which, so far as we could see, was exactly as it was when Russell photographed it in 1890. (See plate 10, National Geographic Magazine, vol. 3, 1891.)

The appearance of Atrevida glacier was that of a rapidly wasting ice- 
tongue, almost if not entirely stagnant in its bulb-shaped terminus. In but one section was pronounced crevassing seen, and that extended over only a small area, in which the ice was bulged upward into a small dome. This was so exceptional a feature in the desert of morainic waste that we took a photograph of it (plate 15, figure 1), interpreting it then as the result of some obstacle over which the glacier was flowing. Unfortunately this was the only photograph taken of Atrevida glacier-a fact which, however, indicates how little of exceptional interest this particular glacier presented in 1905.

Swinging past Terrace point, which bounds the outer end of the valley portion of the glacier on its western side, the Atrevida coalesces with the stagnant terminus of Lucia glacier, which had in 1905, and retained in 1906 (plate 17,'figure 2), the same characteristics as those described above for the Atrevida.

Condition in 1906.-It was our intention in 1906 to cross the Atrevida on our way westward across Malaspina glacier, and until we had reached its very edge, late in June, 1906, we had no intimation of the striking change which had occurred in ten months (compare figures 1 and 2 , plate 15). The alder-covered margin, which we ascended with such ease in 1905, was now transformed to a steep, jagged ice-cliff from which the vegetation had been stripped, down which moraine and boulders were steadily sliding, and from which huge fragments of ice were tumbling (plate 1\%, figure 1). The margin of the glacier had advanced somewhat and now rested in the fringing forest, which was being destroyed by the falling of ice-blocks and boulders into it (plate 16, figure 1). By this advance spruce trees over a half century old were overturned, uprooted, and battered by the forward thrust and the falling blocks of rock and ice (plate 17, figure 1). So frequent were these falls of ice and rock that traveling along the margin was distinctly hazardous, and so steep and jagged was the margin of the glacier that it could be ascended only by the use of ice-axes and the hewing of steps in the ice.

The sliding down of the moraine along the marginal ice-cliff was for'ming a talus which was rapidly advancing into the forest and including battered tree fragments-veritable tree trunk boulders. Where small streams descended, new alluvial fans were spreading out over the mosscovered floor of the spruce forest. The ice-margin was indeed the scene of rapid changes.

The advancing glacier had destroyed the ice-cave from which the stream issued in the previous summer, and the stream now issued from the very base of the ice, beneath a broken and faulted ice-cliff in which 


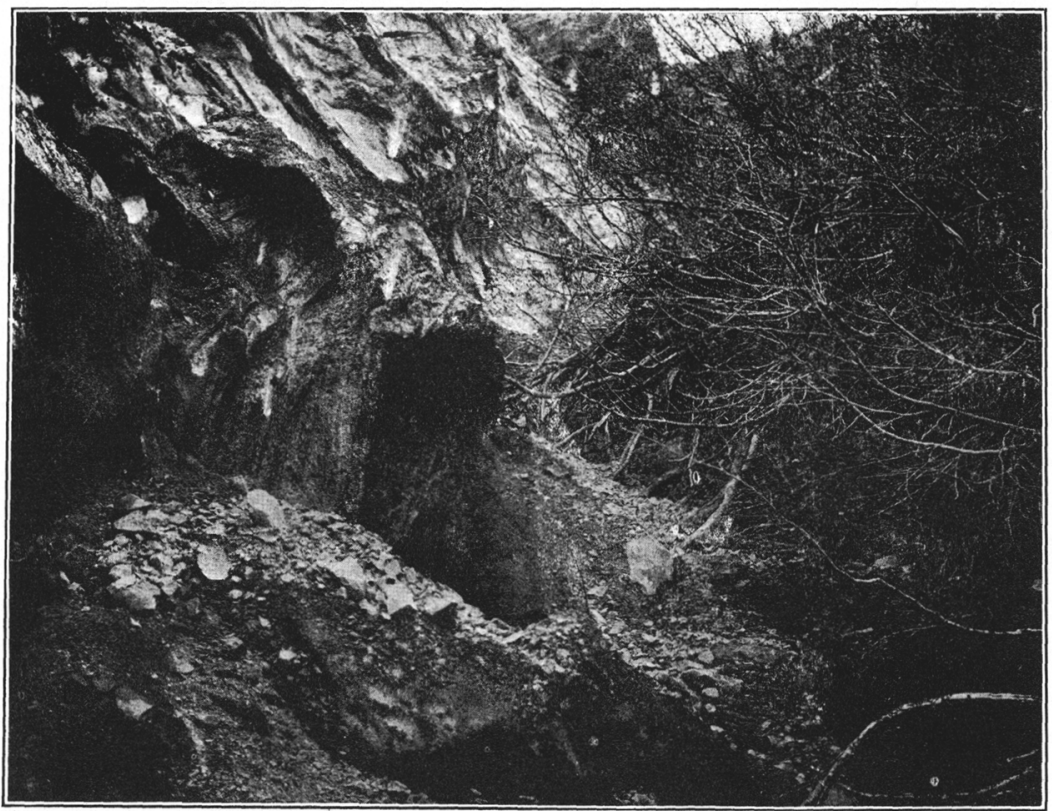

Figure 1.-Eastern Margin of Atrevida Glacier

It is destroying alder thicket, June 29, 1906. In 1905 this was a moderately sloping moraine-covered ice slope

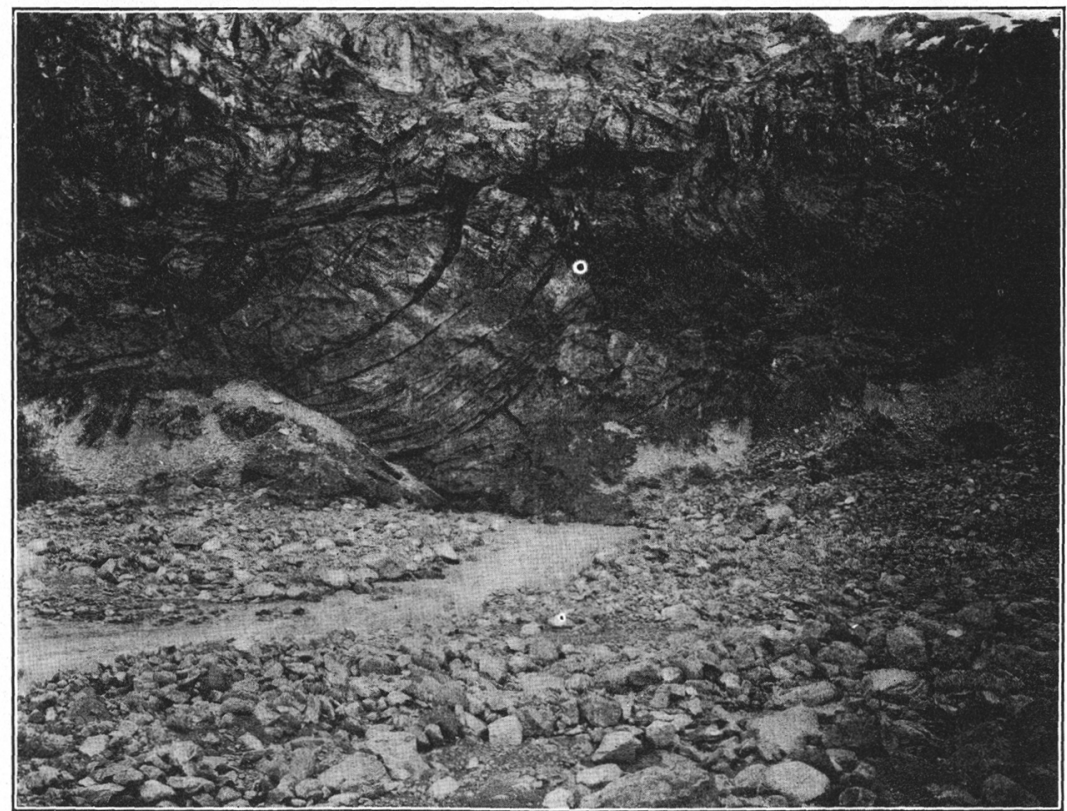

Figure 2.-Broken Margin of Atrevida Glacier, June 29, 1906, where glacial Stream ISSUES

See Russell's photograph (Nat. Geog. Mag., volume 3, 1891, plate 10). This stream emerged from a large ice cave in August, 1905 


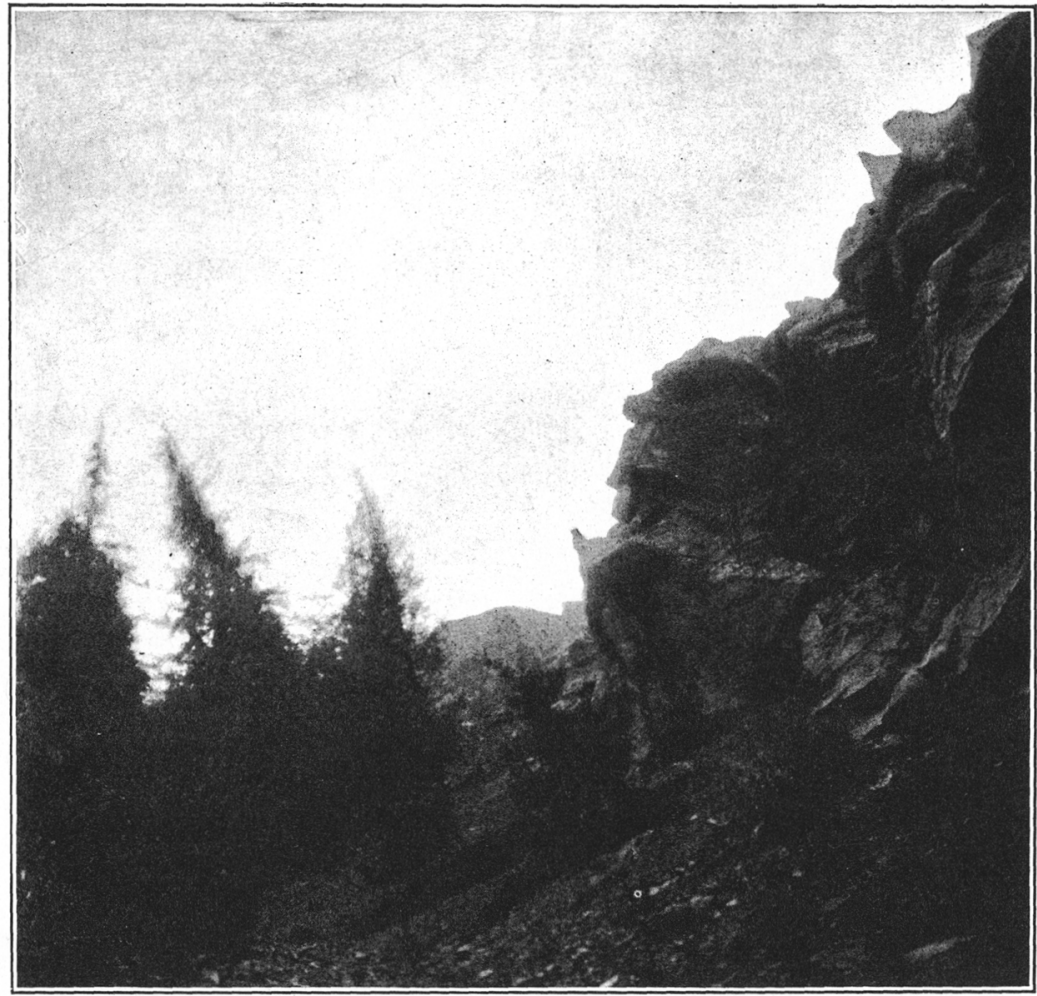

Figure 1.-Broken eastern margin of Atrevida Glacier advancing into Forest In 1905 this was an alder-covered moraine slope. Photograph by O. Von Engeln, July 10, 1906

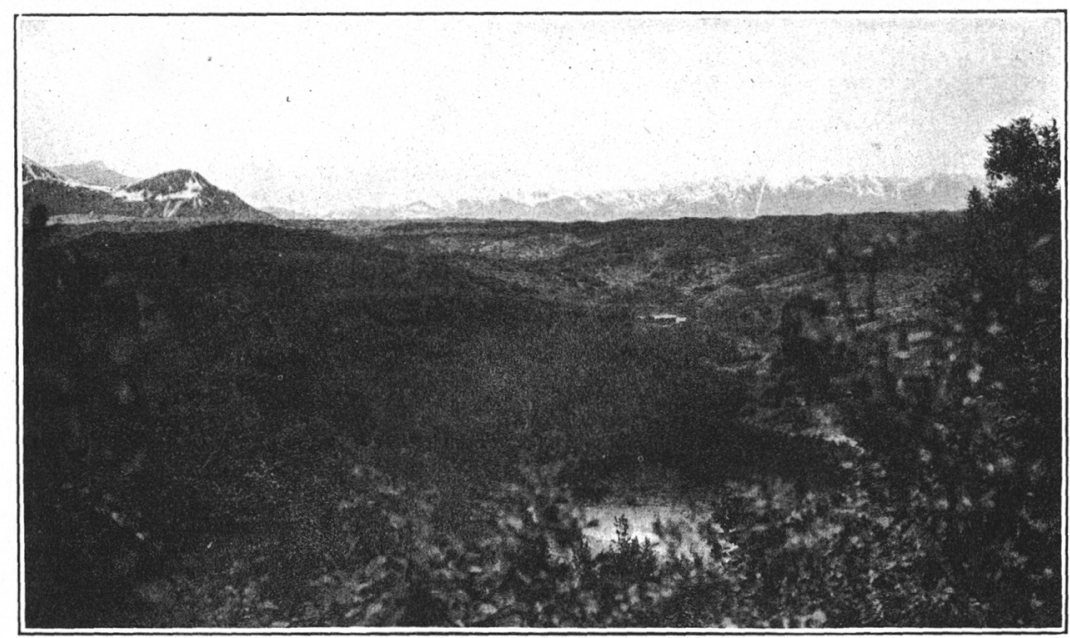

Figure 2.-Stagnaxt alder-covered outer Lucia Glacier from Floral Hills, July 16, 1906

Atrevida glacier was in same condition in 1905 


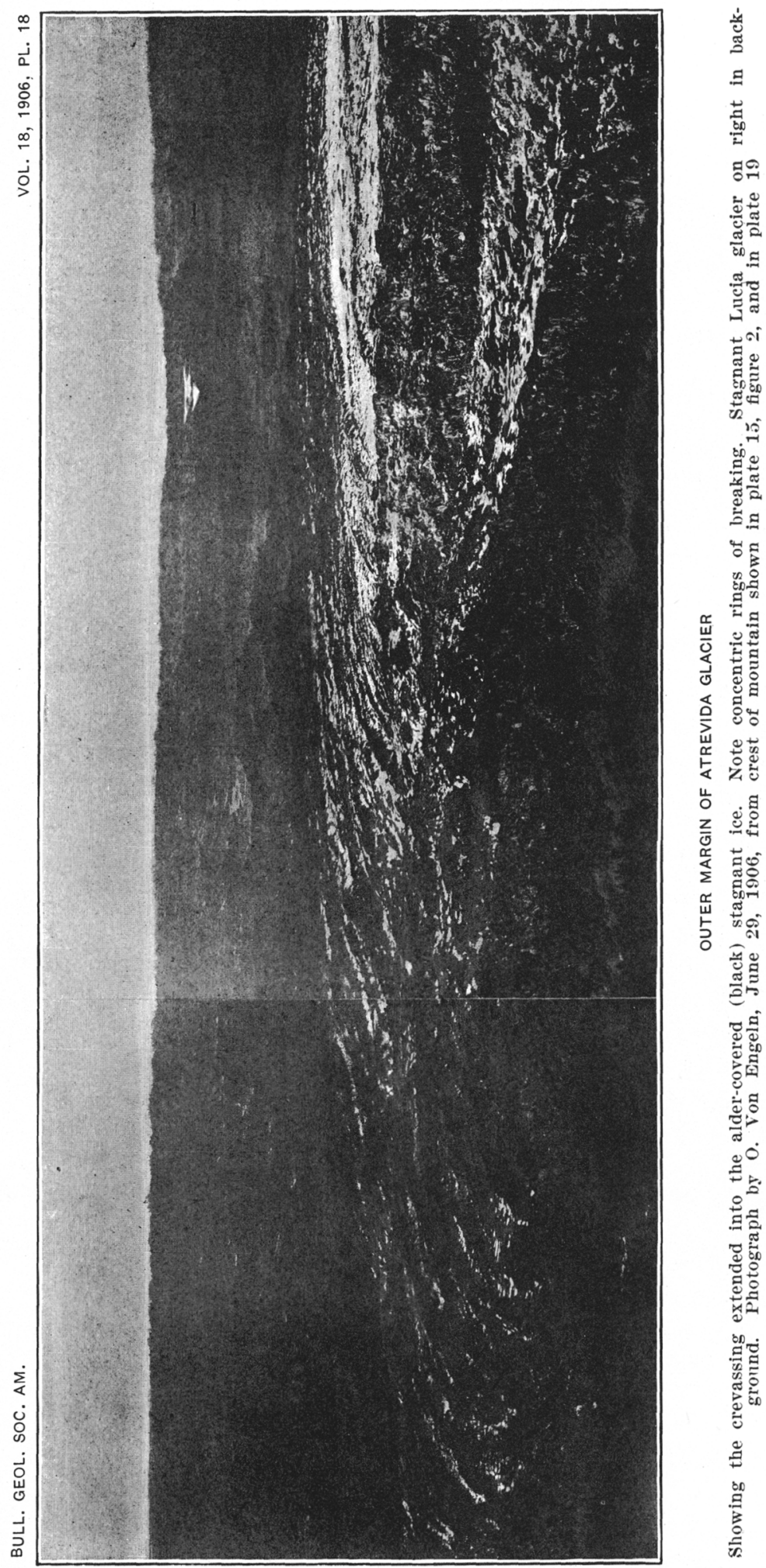



there was distinct evidence of thrust faulting (plate 16, figure 2). At this point the forward movement of the glacier is estimated to have pushed the terminus ahead not less than 100 yards.

It was evident not only that the ice had advanced and become broken during the period of ten months since we last saw it, but that it was even then moving forward. By this movement great crevasses had been opened and the ice, hitherto blanketed by a thick cover of moraine, with forest superimposed on it in places, was now exposed to rapid ablation. As a result of this marked increase in exposure of ice to melting, great streams of turbid water were running away from the margin and down through the forest, where during the previous summer there had been only trickling brooks of clear water which seeped through the morainic soil as the underlying ice slowly melted. Some of these streams flowed where there had previously been no channel, and these were destroying the forest by the deposit of sediment. Others, occupying former brook beds, had cut them deeply, especially where flowing through loose moraine. Altogether it was a wonderful transformation for so short a period, and its effect was shown in Dalton creek, the main glacial stream from the Atrevida, which was greatly swollen as compared to its condition in the previous summer.

The next day, on ascending the low mountain which borders the eastern margin of the Atrevida, we had a bird's-eye view of the glacier from the same point where we had looked down on it the previous summer (plate 18). The change observed from this point of view was even more remarkable than that witnessed at the margin. 'The easily traversed, undulating surface of the moraine-covered outer portion beyond the mountain, and that part farther up the valley which in 1905 was clear ice and snow, were now transformed to a labyrinth of crevasses extending from one side of the glacier to the other. Melting had in places transformed the crevassed surface to pinnacled ice resembling that of a typical valley glacier ice-fall. It had also allowed so much of the moraine veneer to slide into the crevasses that the surface was no longer an undulating waste of moraine, but a broken mass, fully half of whose area consisted of clear glacier ice.

The zone of crevassing extended from near the head of the valley far out beyond the mountain base into the alder-covered terminal portion. It gradually died out in a series of great concentric gashes, bringing to view clear ice in the alder thicket (plate 18). The crevasses were crescentic and roughly parallel to the bulb-like expansion of the glacier beyond the mountain front. By the breaking of the ice, and by its melting, 
the alder growth on the glacier was being destroyed, the soil being removed from around the roots, and the bushes themselves lowered into the crevasses.

Later in the summer we approached Atrevida glacier again, this time from the western side, where we looked down on it from Terrace point (plates 19 and 15, figure 2). From here it was evident that the ice was pushing up against the margin of Terrace point, and it was found that it had moved forward far enough to cover the camp site which Messrs Martin and Butler had occupied in the previous summer. We have no means of telling exactly how far the ice-margin had pushed forward here, but it had evidently advanced several hundred yards. Farther southward the Atrevida had pushed out into the morainic waste of the stagnant Lucia glacier, and its crevassed margin was distinctly higher than in the previous summer, when the unbroken, undulating surface was not noticeably different either in character or in level from that of the Lucia (plate 17 , figure 2 ).

Contrast with Lucia glacier.-According to Mr Butler, who was on both expeditions, the lower stagnant portion of Lucia glacier shows no change in the ten months between the two visits to it (plate 17, figure 2). He believes, however, that above Floral pass there is far more crevassed ice than there was in 1905. It is therefore possible that a wave of advance is in progress in the Lucia, but that it has not yet affected the expanded lower portion. Being a much longer glacier than the Atrevida, the Lucia might well be expected to respond more slowly to the impulse which caused the 1906 forward movement of the Atrevida and the still earlier advance of the Galiano.

Past and future.-In the case of Atrevila glacier, a long period of repose and wasting has terminated in a sudden forward rush of such force as to break the ice into an impassable sea of crevasses. We do not know how long this period of repose had lasted. It certainly dates back before Russell's crossing in 1890, and judging from the maturity of the fringing forest and of the alder growth on its outer portion, it seems prolable that this part of the glacier has been essentially stagnant and slowly wasting for not less than half a century. At the time of our visit, the forward thrust had not yet reached its maximum, and therefore we cannot tell how much farther it will extend; nor can we predict whether its effects in breaking the ice will outlast the first rapid forward rush. If the Galiano glacier may be taken as a guide, however, it may be expected that the forward movement will be short-lived and quickly followed by a period 


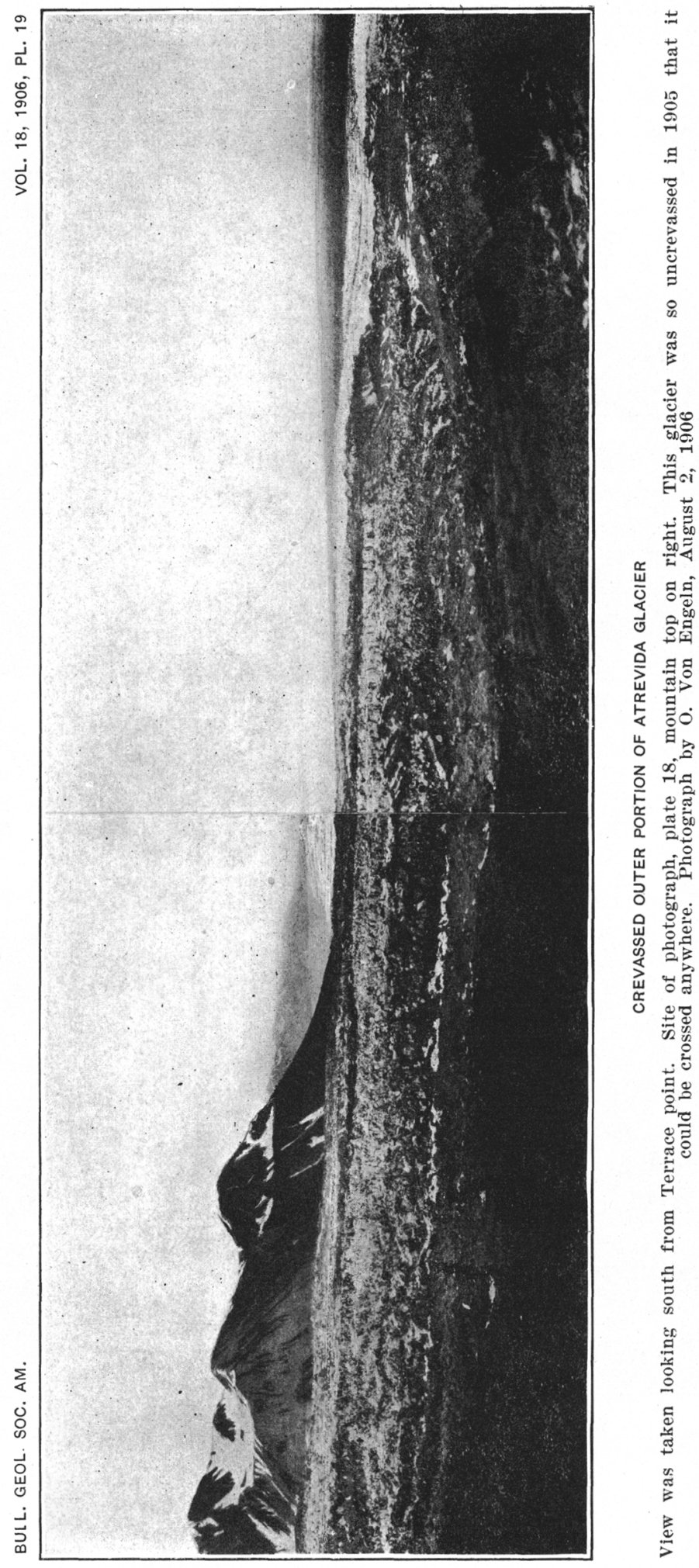




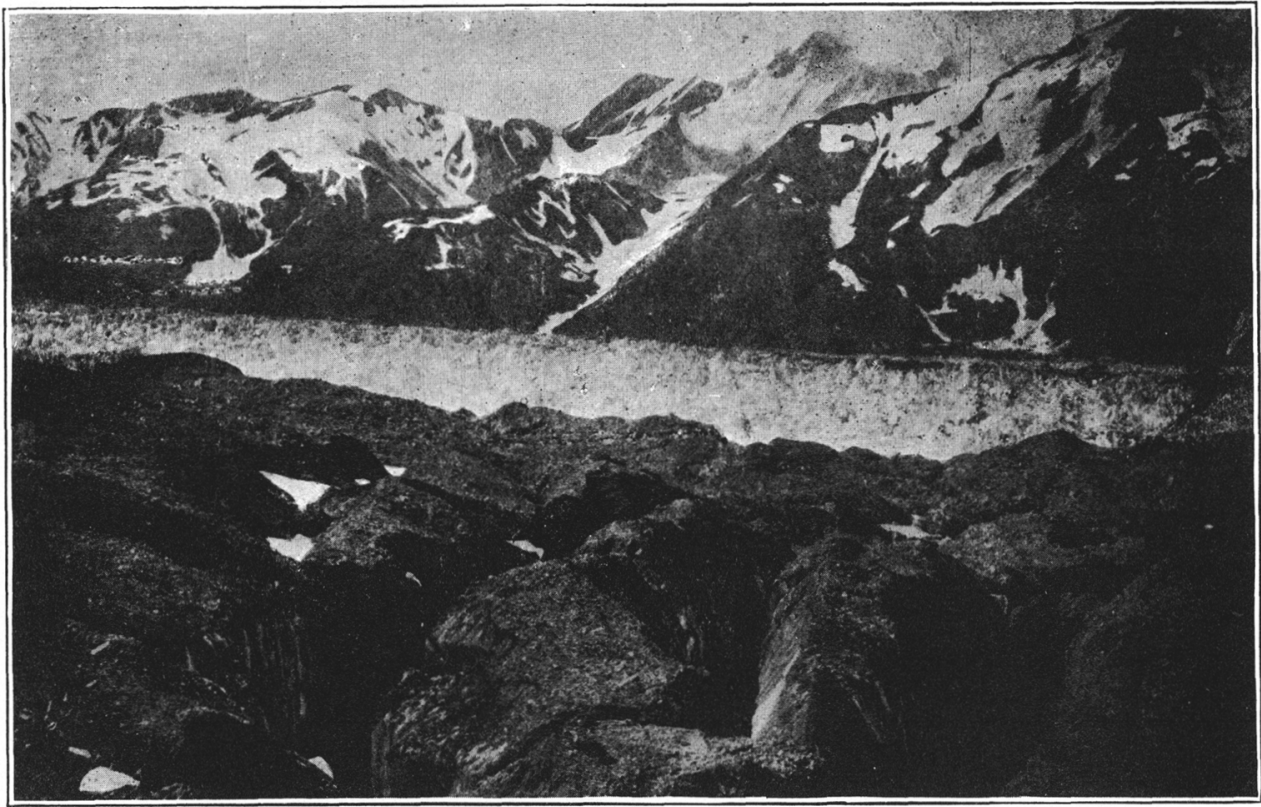

Figure 1.- Sea of Crevasses in Marvine Glacier

At this point the glacier emerges from mountain valley. Here Russell easily crossed in 1890 . Long-focus photograph by O. Von Engeln, July 30, 1906

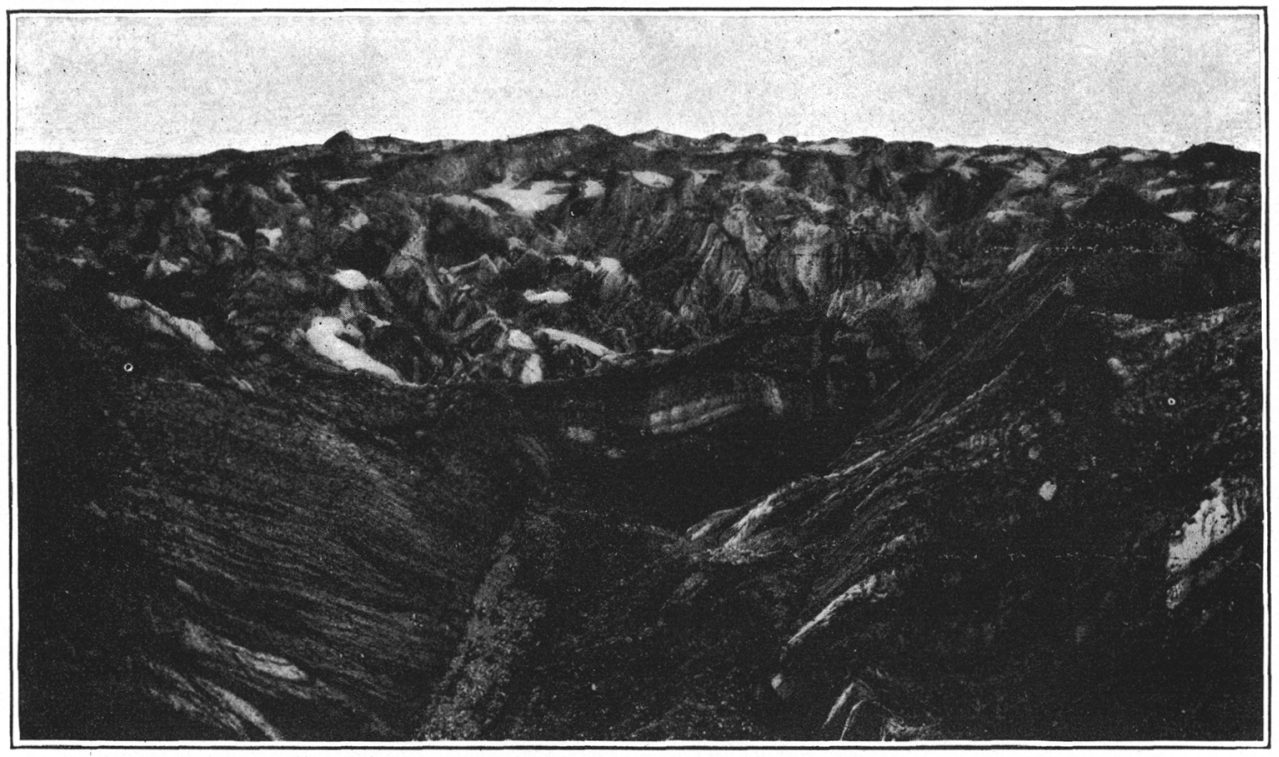

Figure 2.-Detail in Crevassed mastern margin of Marvine Glacier at Blossom island

Photograph by O. Von Engeln, July 29, 1906 
of repose, accompanied by a return of the moraine-covered condition and growth of an alder thicket on the outer margin.

\section{MARVINE GLACIER}

Previous condition.-We did not visit this glacier (plates 20-23) in 1905, but had clear views of it, through field glasses, from several points, the nearest being that obtained by Messrs Martin and Butler on the western side of Floral pass, where only the Hayden glacier intervened. Russell crossed it near Blossom island in 1890, and on his retreat in 1891 he traveled over its seaward margin from point Manby to Kwik river, where it forms the eastern part of Malaspina glacier. Abruzzi and Bryant, in 1897, starting at Osar river, near point Manby, on the shores of Yakutat bay, entered on their explorations by first crossing the seaward end of that part of Malaspina glacier which is dominated by the Marvine. From the description of these explorers, it is evident that both Marvine glacier and the eastern part of the Malaspina, which the Marvine supplies, were then smooth and easily traversed. Our distant views in 1905 led us to believe that it was not then altered from this condition. Had the glacier then been crevassed even approximately as much as in 1906, when the broken surface was readily visible from a distance, even to the naked eye, we surely could not have overlooked it.

Condition in 1906.-In July, 1906, we traveled along the eastern margin of the Malaspina and Marvine glaciers to a point 3 or 4 miles beyond Blossom island, returning in August along the same route, in each journey crossing Hayden glacier with ease. Later we skirted the seaward face of the Malaspina as far as point Manby. We also looked down on it from several high points, so that in the course of the season we saw the entire Marvine glacier from the sea well back into its mountain valley.

The entire glacier margin, from point Manby well into the mountain valley to the north of Blossom island, is impassably crevassed. Where Marvine glacier emerges from the mountains it is a sea of crevasses from side to side and as far up the valley as we could look (plate 20, figure 1).* It is therefore now utterly impossible to cross this glacier where Russell traveled over it so easily in 1890. From this point to the sea, a distance of not less than 15 miles, the piedmont ice plateau is broken by a maze of crevasses, rendering the entire eastern portion of Malaspina glacier now impassable (plate 20, figure 2). This crevassed

* Owing to an accident, by which I was upset in the Kwik river, the photographic plates which were in my pack were in the water about five minutes, which accounts for the bad condition of this and some of the other pictures.

XXIV-BUll. Gwol. Soc. AM., Vor. 18, 1906 
area broadens seaward, starting with a width of 3 or 4 miles at the mouth of the mountain valley and expanding to a width of over 10 miles near the sea.

In the mountain valley the crevassing has produced a jagged, pinnacled ice surface (plate 20, figure 1), but out in the expanded portion of the Malaspina piedmont area the crevasses form great rents, with many table-top areas between-remnants of the former level-topped ice-plateau Owing to the elevation, the snow had not completely disappeared from this section in July; so that, excepting along the glacier margin, melting had not yet greatly modified the area between the crevasses. This fact clearly points to the conclusion that the crevassing is a result of movement in the season of 1906; for if the broken surface had been exposed longer to the air, melting would necessarily have produced much greater effect in rounding off the table-topped areas between the crevasses.

That the advance of Marvine glacier was in progress during the summer of 1906 was abundantly proved. The margin of the glacier was being pushed forward into the form of a jagged ice-cliff resembling that of Atrevida glacier (plate 21). During this forward push the ice had been broken into great blocks, and the morainic soil, which varied in depth from 2 to 15 feet, had been greatly disturbed. The broken iceblocks, stained by a veneer of debris washed down over them, reminded one of some of the frost-riven granite cliffs of New England, and at a distance looked far more like rock than ice. Ice-blocks were seen to tumble from the glacier margin as we passed along it, and the morainic soil was constantly falling from the cliff and being incorporated in the new talus slopes and alluvial fans.

By exposing to the air so much ice that had previously been deeply blanketed beneath moraine and forest, melting was greatly increased, innumerable new streams were developed (plate 23), and the volume of $\mathrm{K} w i k$ river greatly augmented. That this process was then actually in progress was clearly proved by the changes which occurred during the month that elapsed between our journey to Blossom island and our return. In this interval some of the streams had grown noticeably in volume and headed farther back in the crevassed ice, in some cases having developed ice-tunnels; the talus slopes and alluvial fans had grown in area, and in places the ice-margin had become distinctly altered in form.

By the forward thrust and breaking of the ice, the forest growth on it was being destroyed (plate 22). Many of the trees were inclined at various angles; others had fallen down the ice-front or into the crevasses; and large numbers were seen or heard to fall during our passage along 


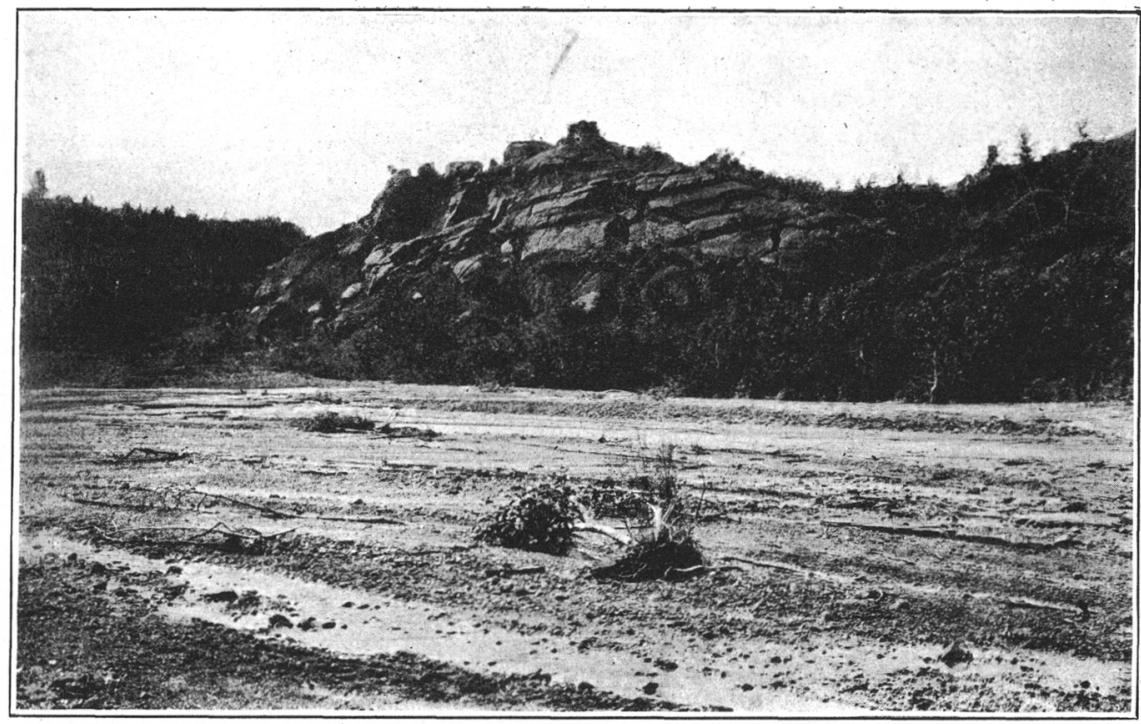

Figure 1.-Broken Ice Cliff of Malaspina margin from Kwik River Photograph by O. Von Engeln, August 11, 1906

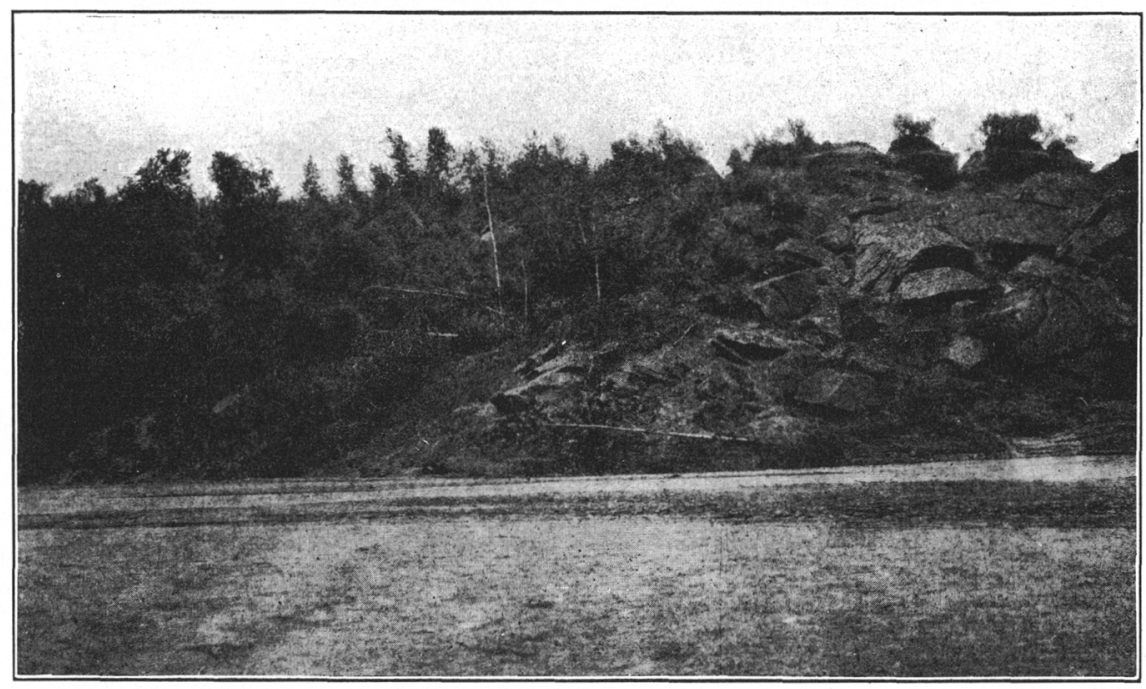

figure 2.- ICe of eastern Margix protruding through Forest Cover

Note broken ice blocks and overturned trees. Photograph from Kwik river, July 14, 1906 


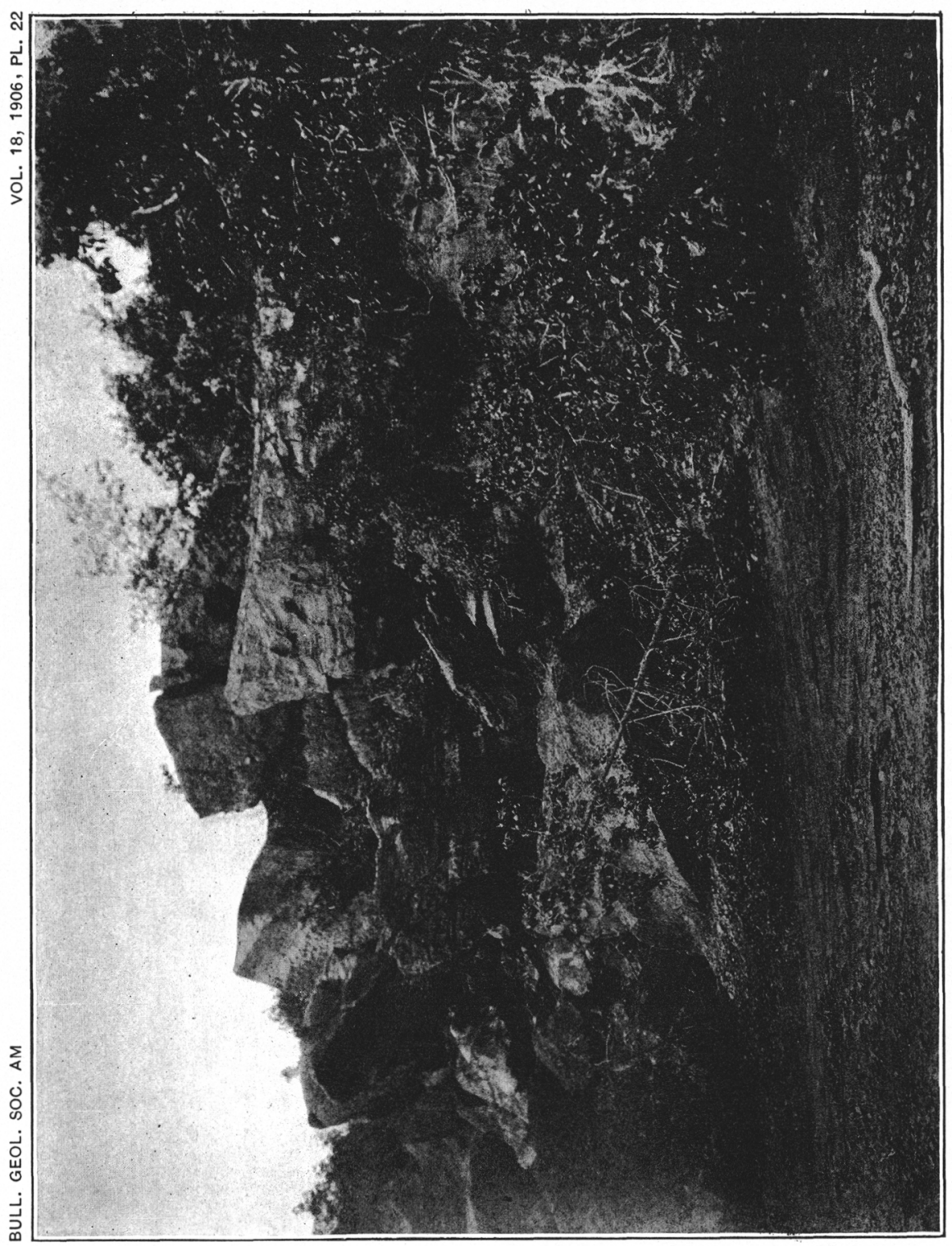

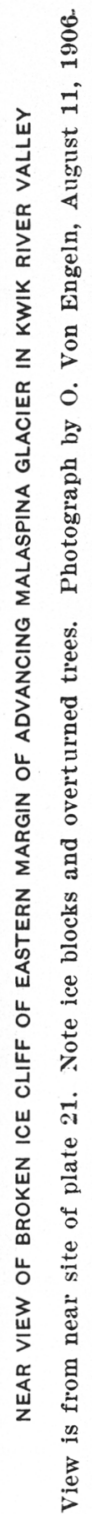



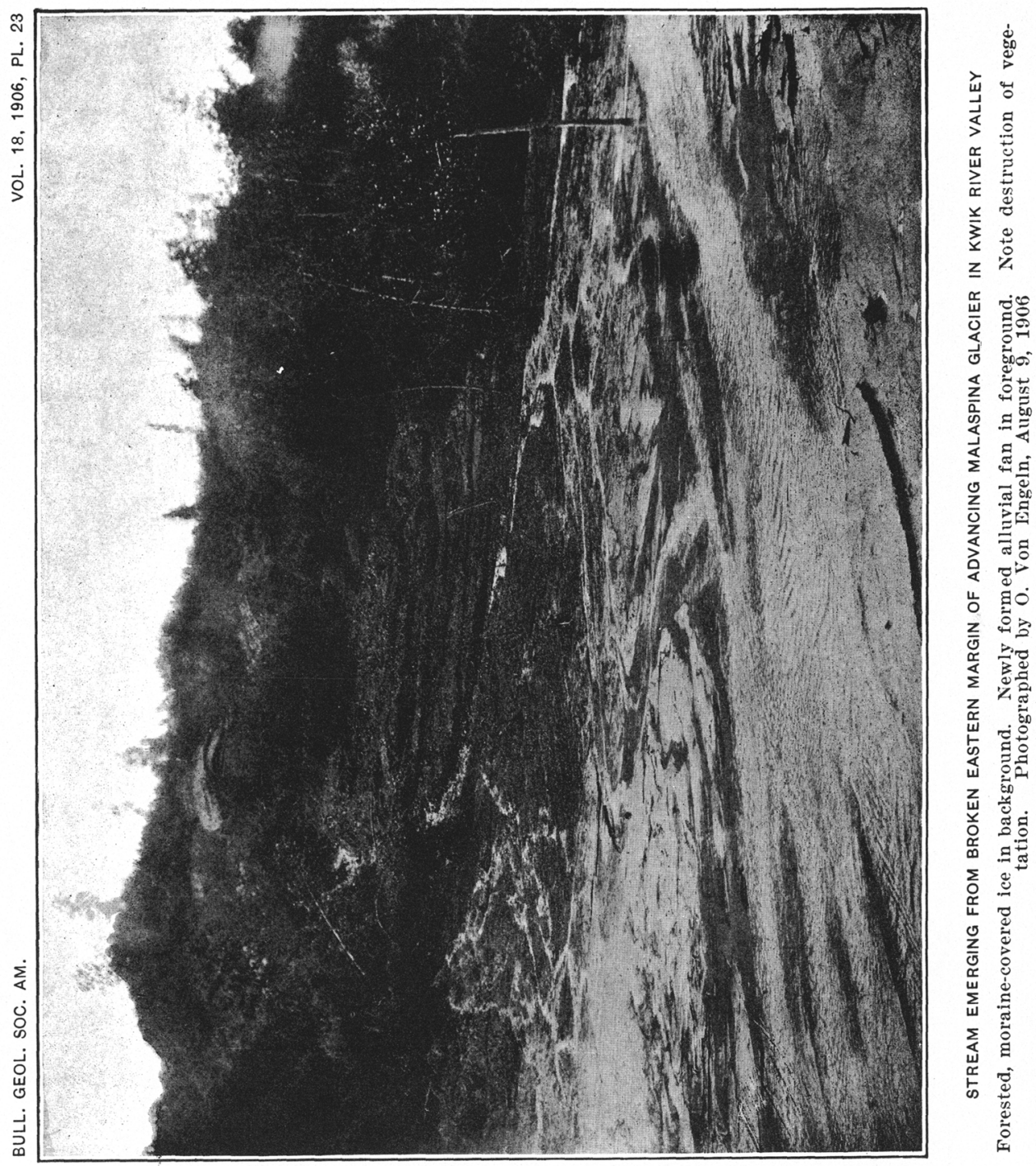
the ice-front. In many cases the soil had been removed from around the roots, and in consequence the vitality of the plants had been so sapped that their leaves had assumed the colors of autumn. Of these trees, fallen or otherwise, none were seen which had not completely developed their leaves, which proves conclusively that the forward thrust, along this margin at least, had its beginning after the spring season. Many of the cottonwood trees growing on the margin of the glacier were at least fifty years old, so that the essentially stagnant condition of the glacier, now abruptly interrupted, must have had a duration of at least half a century.

Rapid geologic changes.-The sudden transformation to liquid water of this latent supply, locked up in ice and blanketed beneath debris, has opened possibilities for rapid geologic changes succeeding a long period of stagnation and inactivity. This was well illustrated by the changes that occurred in the glacier margin immediately back of a camp site which we occupied on the west side of the Kwik. Early in July a small stream emerged from the broken ice and flowed past our camp, passing through a small lake in which it was building an alluvial fan (plate 23). During our stay at this camp we were every few minutes disturbed by the sound of falling ice-blocks, the crashing of falling trees, and the sliding down of large quantities of morainic soil. The melting ice supplied so much water that streams of liquid mud were constantly descending the ice-face, building up mud-flow fans along the base of the ice into which one dared not step. These deposits advancing into the fringing forest are rapidly destroying it (plate 23).

On our return a month later this small stream was greatly swollen, the fan was much larger, and the lake was nearly destroyed. In the meantime the detailed form of the glacier was totally altered. Leaving some supplies cached here for three days, on our return we found them almost undermined by the stream, which in the meantime had more than doubled its volume.

Since the entire eastern margin of the Malaspina, not only along Kwik valley, but also along the Yakutat Bay front, is in a similar condition, this sudden supply of water, acting on the morainic debris residually accumulated through years of slow ablation, is producing important changes over a wide area. It is a marvelous change, and in a single season more work of transportation and deposit has been accomplished than for scores of years immediately preceding. Another season of exposure to sun and rain will have removed most of the accumulated debris and forest from the margin of this advancing and broken glacier. 
Change in subglacial stream course.-One rather peculiar effect of the advancing Marvine glacier was illustrated at Blossom island, situated in the bay where the western margin of the Hayden and eastern margin of Marvine glaciers unite. Streams supplied from the Marvine, and from several small valley glaciers, unite here to form a fairly good-sized river, which, after expanding in a small lake at the ice-margin, emerges to pass into a subglacial tunnel, from which it escapes as the Kwik river after a journey of 5 miles under the ice.

Just before our visit the Blossom Island lake had been greatly enlarged, covering an area several times its present size and rising 25 or 30 feet above its present level. The proof of this rise was the presence of a recently deposited layer of fine glacial mud, the occurrence of stranded icebergs above the lake level, and the retarded development of vegetation. In the areas that had been submerged the annual plants had only just begun to sprout, although it was the middle of July, and the alders and willows had only begun to put out their leaves, while some of the bushes nearer the lake had not begun to sprout.

In seeking a cause for this expansion of the Blossom Island lake, we found that the course of the outflowing stream had been entirely changed. Formerly it had flowed out through a small bay in the ice at the junction of Hayden and Marvine glaciers, doubtless disappearing in an ice-tunnel. The forward push of Marvine glacier had evidently destroyed this tunnel, but it had not completely destroyed the bay in the ice through which the water flowed on its way to the tunnel. About a mile to the north a new outlet had been developed under Hayden glacier, which is not subjected to the forward thrust. 'The newness of this outlet was proved by the fact that the great torrent of water was rushing under the glacier without the development of an arch. The current licked the ice-foot at the base of a cliff fully 200 feet high, from which large masses of ice were falling every few minutes. Occasionally great slices, thousands of tons in weight, slumped into the torrent to be swept in pieces under the glacier. By thie action a bay over a hundred yards long had already been eaten into the glacier; and beyond this, for a distance of several hundred yards, the ice under which the stream flows is broken by slumping.

The shifting of a subglacial stream course by the advance of Marvine glacier, evidently the work of the season of 1906, is therefore another of the peculiar effects accompanying the remarkable advance of the glaciers of this region. When the new outlet was opened it must have caused a sudden increase in the volume of the Kwik. In fact, it is probable that our packers witnessed it; for a cache containing most. of our provisions, 
placed one evening in what seemed a safe position, was swept away early the next morning by a sudden rise in the river.

\section{OTHER TRIBUTARIES TO MALASPINA GLAOIER}

Between the advancing Atrevida and Marvine glaciers lie Lucia and Hayden glaciers. It has been stated that the former may possibly be advancing in its upper portion; but there is no sign of any advance in the Hayden. It pushes down to and coalesces with the Marvine, slightly deflecting it, but not contributing greatly to the ice-supply of Malaspina glacier. For a short distance near the head of the Kwik, ice supplied by Hayden glacier forms the eastern margin of the Malaspina, and in this section there is little crevassing; but, with the exception of this small area, there is no place between point Manby and Blossom island where one can ascend to the surface of Malaspina glacier without encountering almost impassable crevasses.

West of Marvine glacier the Seward emerges from its mountain valley, spreading out to form a portion of the Malaspina ice-plateau. From a distant view that part of the Malaspina which Seward glacier supplies does not appear to be greatly crevassed, the broken area dominated by the Marvine ending quite distinctly where it comes in contact with the ice supplied by Seward glacier; but where the Seward emerges from its mountain valley, there is a great deal of crevassing. Benno Alexander, a member of my party, accompanied the Duke of Abruzzi on his ascent of mount Saint Elias, in the course of which he frequently traversed Seward glacier. On viewing this glacier from the crest of Blossom island in 1906, Alexanderwas convinced that it was far more crevassed than in 1896. He states that in 1896 it was easy sledging across that part of Seward glacier where now, from a distant view, it seems that sledding would not be possible. This suggests that possibly Seward glacier is also advancing, but that the wave has not yet affected the more stagnant piedmont terminus in the Malaspina ice-plateau.

\section{SUMMARY OF OBSERVATIONS}

The facts above stated for individual glaciers show that there is a remarkable change in progress in at least several of the many valley glaciers of the Yakutat Bay region. This change is in the nature of a paroxysmal thrust, as a result of which the ice is badly broken, as if a push from behind had been applied with such vigor as to break the rigid, resisting ice-mass in front. The effect of this thrust is in each case felt from far 
up the mountain valley well down toward the terminus of the glacier, and, in the case of Marvine glacier, to the very end.

In both Variegated and Atrevida glaciers the ice has been broken for a distance of from 5 to 7 miles; in Marvine glacier the breaking extends fully 15 or 20 miles. The crevassing in all cases extends completely across the valley portion of the glacier and down into the stagnant or nearly stagnant moraine-covered margin. In all cases the thrust is accompanied by a distinct forward movement at the terminus, and in at least three cases - the Variegated, Haenke, and Atrevida glaciers-there has been a distinct thickening of the ice as a result of the forward thrust. It is probable that there has also been a thickening in Marvine glacier, but since we did not visit it in $\mathbf{1 9 0 5}$, we have no comparative observations on which to base a definite statement.

The remarkable advance of these glaciers is recent, and, in the case of four of them, has mainly, if not entirely, occurred in the ten months preceding June, 1906. Not only is the movement recent, but it was actively in progress at the time of our visit in the summer of 1906. In at least one case, that of Galiano glacier, a forward movement has occurred and died out during the interval between 1890 and 1905 . There are indications that an advance is beginning in some of the glaciers, notably the Lucia and the Seward, but there are others which show neither signs of the coming of such an advance nor of its having already come and gone.

From these facts it appears that, for some reason, there is a striking and rapid change in progress in the glaciers of the Yakutat Bay region, interrupting a period of long quiet and affecting different glaciers at different times. One glacier has passed through the cycle of change; others entered on it in 1906; still others show signs of the beginning of such a cycle; but in other cases there are no indications of its approach.

\section{Consideration of Hypotheses}

\section{THE PROBLEM TO BE SOLVED}

Such a remarkable change in the condition of glaciers as to transform an unbroken, moraine-covered valley glacier to a sea of crevasses in the short interval of ten months--a phenomenon, so far as I know, not hitherto recorded-calls for a special explanation. The phenomena in the field clearly prove that there has been a wave of advance passing through the glaciers with such rapidity as to break the ice, instead of causing a slow forward movement, such as commonly results from normal climatic 
changes. This fact demands for its explanation a cause sufficiently powerful to start such a rapid wave.

\section{HYPOTHESIS OF CLIMATIC CAUSES}

In seeking an explanation for the advance of a glacier, one naturally, first of all, considers climatic causes. In the attempt to apply this explanation to the case in hand, two serious difficulties have arisen. In the first place, no such profound result from climatic variation has ever been noticed before. In the second place, it seems impossible that the amount of additional snowfall required to start such a tremendons wave of advance could be supplied by seasonal variations, for it would mean a sudden and great increase in the snowfall, interrupting a half century of fairly uniform conditions. There is no direct evidence against this hypothesis, for we have no rainfall records in this region; but nevertheless we seem warranted in dismissing it merely on the basis of improbability, for such a profound, sudden change in climate would of itself be more remarkable than the phenomenon which we are called on to explain.

\section{HYPOTHESIS OF POSSIBLE UPLIFT}

A second hypothesis that has been considered is that of uplift. Concerning this, also, we have no definite facts to advance; but against it may be argued the improbability of so decided a change in so short a time as to profoundly disturb the glaciers radiating from a mountain center. To produce such an effect, an uplift would need to amount to at least hundreds of feet and to take place in a brief interval of time. In fact, since the glaciers all head in lofty, snow-covered mountains, up whose slopes damp ocean winds rise and on which the snow-cover descends to within two or three thousand feet of sealevel, it is very doubtful if the amount of snowfall on the mountains would be greatly increased, even if there had been a sudden uplift of hundreds of feet. This hypothesis is so utterly improbable that it also may be dismissed without further consideration.

\section{HYPOTHESIS OF CHANGE OF GRADE}

We gave consideration to the hypothesis of change of grade in the valley glaciers as a result of alterations of level accompanying the earthquake of 1899. This explanation also lacks probability, for a change in grade sufficient to transform a nearly stagnant valley glacier to one as badly crevassed as an ice-fall is wholly unlikely. Moreover, in the case of Atrevida and Variegated glaciers at least, the grade was essentially the 
same in 1906 as in 1905, and in both cases it was far too low to account for movement rapid enough to so break the ice (plates 8 and 19). It is evident that the cause of the crevassing must be sought not in the influence of grade, but in an acceleration of motion due to a push from upstream, acting on low grade glaciers whose forward motion up to 1905 was so slight as to admit of the concentration of surface morainic debris.

\section{HYPOTHESIS OF BREAKING BY EARTHQUAKE SHOCKS}

Two hypotheses involving earthquake effect were considered and quickly dismissed. One of these was that some recent earthquake had so shaken the region as to break the ice into the condition observed in 1906. This hypothesis was readily disproved on inquiry, when it was found that there has been no notable earthquake in the Yakutat Bay region since 1899.

The second earthquake hypothesis was that the shock of 1899 was responsible for the conditions of 1906 by actually breaking the ice, though the effects are only just now appearing at the surface. Numerous facts disprove this improbable hypothesis, the most fatal being the convincing evidence of forward movement actually in progress in the summer of 1906. As has been shown above, the charge is associated with and apparently the result of a forward push, so that any hypothesis which does not include this is necessarily eliminated.

HYPOTHESIS OF SNOW SUPPIY RESULTINA FROM EARTHQUAKE SHAKINA

This hypothesis is, in a word, that during the earthquakes of 1899 the mountains from which the snow supply of these glaciers is derived were so vigorously shaken that great avalanches of snow and rock were thrown down to the névé, starting a vigorọus wave of advance whose effects have now reached the glaciers described above. Of all the hypotheses which have suggested themselves, this alone seems capable of explaining the phenomena. Opposing it no facts have been discovered, while there is much in its favor.

The earthquake of 1899 was of unusual vigor.* Throughout a period of seventeen days the region was subjected to earthquake shocks, some of which were of exceptional strength, notably those on September 10 and September 15. The most violent shocks were so strong that they were plainly recorded on the seismographs in Europe, Japan, and at cape of Good Hope. During these earthquakes the coastline of Yakutat bay was greatly deformed-in one place, on the west side of Disenchantment bay, the beach being hoisted forty-seven feet above sealevel. The people living

\footnotetext{
* Tarr and Martin : Bull. Geol. Soc. Am., vol. 17, 1906, pp. 29-64.
} 
at Yakutat, the nearest inhabited point, report long-continued, terrifying shaking of the ground. Some prospectors who were in camp near Variegated glacier made a similar report, adding to it the statement that during the most violent shaking the air was filled with noises like thunder, as huge avalanches of snow and rock descended the neighboring mountain slopes.

There can be little, if any, question that during these shocks immense quantities of snow and rock were thrown down from the steep mountain slopes. The snowline descends to within two or three thousand feet of sealevel, and the mountains rise to elevations of from ten to fifteen thousand feet, so that the snow-covered slopes occupy a great area (plate 11). By glacial erosion and other forms of denudation the valley slopes have been greatly steepened, and therefore over large areas the snow lies in very unstable positions. Even under ordinary conditions snow avalanches may be seen at almost any time among these lofty mountains. This is especially true during and after snowstorms, which are frequent in September, the month during which the earthquake of 1899 occurred. When to this heavy snow blanket, which mantles the steep mountain slopes, is added a repeated shaking of the mountains, it follows that a great and sudden addition to the névé must in all probability have taken place.

A comparison of the present conditions with photographs taken by Professor Russell clearly shows that in some cases, at least, there was a downshaking of materials from the steep valley slopes. In two cases where these comparisons were possible-the valleys of Black and Galiano glaciers-there have been notable changes. In Black Glacier valley extensive areas, which in 1890 were covered with vegetation, are now bare rock. In Galiano valley large patches of snow and ice which clung to the steep slopes in 1890 have now disappeared (compare figures 1 and 2, plate 13). In this valley also the effects of recent great avalanches are still plainly visible, and on Hayden glacier there is an enormous mass of debris which evidently has fallen recently.

That therewas abundant cause for an unusual down-sliding of snow,ice, and rock in 1899, and that this downfalling actually did occur, I believe the above facts amply prove. A notable accession of supply in the névé region, such as these facts indicate, must of necessity start a wave of advance in the glacier, and this wave would naturally be a great one-far more powerful and sudden in its effects than is liable to be produced by normal climatic variations. One possible difficulty in the way of acceptance of the explanation here proposed is the briefness of time for the 
transmission of this great wave; in fact, this difficulty has led me to question whether it may not be necessary to seek an explanation in an earthquake of more remote date. Facts bearing on this question are not at hand.

So far as I know, no similar phenomenon is reported from other regions for comparison. It is well known that normal climatic variations cause a slow wave of advance, but exactly what would follow upon a sudden and abnormal accession of snow supply is not clear. So far as I am able to consider the question, however, I am led to believe that it would not be proper to make use of the results of normal climatic variations as an exact parallel in a consideration of the effects which would follow upon a sudden accession of enormous quantities of snow and ice. It seems probable that so great an increase in supply would start a wave of such power as to crowd upon the rigid and nearly stagnant ice of a wasting glacier. Such a crowding, by applying a rapid thrust against the ice, might well push it so hard and fast as to cause it to slide forward, and cause it to move by massive breaking instead of by interstitial movement. It is conceivable even that the effects of such a wave might advance faster than the wave itself.

To state the latter point more fully, when a great wave of advance, starting in the névé region, reaches the glacier proper, it might exert sufficient pressure to push forward the ice in front of it, and thus cause it to break, pile up, and advance even down to the very margin. In this way the effects of a great wave of advance might well extend clear to the end of the glacier long before it would be possible for a normal wave to reach the terminus. Some such process as this seems demanded by the fact that miles of ice are suddenly, in a period of not over ten months, changed absolutely from a surface easily traversed to a labyrinth of crevasses.

If ice near the bottom of the glacier is moving by viscous flow, the sudden application of pressure, due to great accession of supply, may cause a more rapid flow of the bottom layers, and thus greatly rupture the rigid upper layers.

\section{GLaciers that are Not advancing}

That some glaciers are advancing and others not, suggests the possibility that there is some selective action, as a result of which certain glaciers are immune from the effects which have caused such a remarkable advance in others; but this may be only apparent. If the cause for the advance is earthquake shaking, it ought in time to affect most, if not all, 
the glaciers of the region; but there is no reason to expect that the effect would occur at the same time, or to the same degree, in the different glaciers. There are at least three reasons why the effect may vary in time, or in intensity, or in both. Of these, doubtless the most important is the length of the glacier, and in this connection it is notable that one of the smallest glaciers, the Galiano, has already passed completely through a period of advance; and that Atrevida glacier now shows the full effects of the advance, while its longer neighbor, the Lucia, has not been affected, excepting possibly in its upper valley portion. On the other hand, the long Marvine glacier, a far greater ice-stream than the Lucia, has entered on the maximum development of the effects, while some very short glaciers, like the Black, just south of the Haenke, show neither signs of having passed through the period nor of its approach.

These contrasts, however, may be due to one or both of the other two possible causes for variation in the effects of the earthquake shaking. One of these is the steepness of the valley walls, especially in the snowfield section; the second is the amount of snow available. Obviously there must be great differences in the steepness of the mountain slopes and in the amount of snow available in unstable position; and, according as these conditions favor or oppose a sudden increase in the névé supply, there will be marked variations in the rate and amount of consequent advance. A possible fourth cause for variation in the effects of the earthquake shaking is difference in intensity of shocks from place to place. While undoubtedly the entire region was severely shaken, it is probable that some portions of the area escaped with far less disturbance than others, and consequently with a much smaller addition to the névé.

There are therefore adequate explanations for the differences observed in the condition of the various glaciers. Some, quite certainly, will never show the effects of the earthquake shaking; others, which have not yet advanced, may be expected to push forward at a later time. It cannot be definitely predicted when this will occur in any individual case, but from the rapidity with which the advance has swept throughout the entire length of some of the glaciers, it seems probable that the effect of the wave will become manifest within a very short period of time in all cases where the cause for the advance has operated. Therefore it may be predicted that, in all probability, this region will be one of great interest to glacial geologists in the next few years. It is highly probable that Malaspina glacier, for so long a period a nearly stagnant ice-plateau, will become crevassed throughout its entire length, and, advancing along its margin, possibly enter the sea, discharging icebergs both into Yakutat bay and the 
open Pacific along a coast where at present the glacier front is faced by strips of alluvial fan and beach.

\section{Consideration of the future Condition}

In addition to the possible future advance of other glaciers, it is interesting to consider what may be expected to follow on the advance of those glaciers which have already been affected. On this point Galiano glacier throws much light. If we are warranted in basing our conclusions on this glacier, we may infer that in each case the wave of advance will soon die out, that stagnation will follow, and that ablation will proceed to again mantle the margins with a cloak of morainic debris.

Much of the moraine formerly available for this mantle will have been lost as a result of the breaking caused by the recent advance. Some of it will have tumbled down into the crevasses, and much of it will have been carried away by the newly born streams. The removal of this material will leave less to blanket the ice and to prevent it from wasting away. For this reason a more decided recession of the margin of the glaciers would be expected in the immediate future. This more rapid recession may be expected to be increased by a diminished supply of ice; for, since the shaking down of quantities of snow in the supply ground has in places removed the accumulation of many years, until such time as its place is taken by additional snow accumulation, there should be a decided deficiency in supply. One may therefore fairly predict a distinct recession following the notable present advance.

\section{Grologic EFfects}

The sudden breaking of extensive areas of glacier ice and the advance of the broken glacier margins give rise to some very notable geologic changes. By the advance in at least two instances, the course of goodsized glacial streams has been completely altered. The cracking of the glaciers opens to ablation an enormous area of ice hitherto protected by debris or buried beneath the surface of the previously smooth glacier. Our observations on Hayden glacier prove that in the last of July and early August the level ice-surface is lowered 4 inches a day by ablation. By the great increase of exposed ice the volume of water emerging from the glaciers is quickly and enormously increased. The accumulated moraine on the surface, and particularly along the glacier margins, furnishes an immense quantity of debris; so that not only is the volume of the glacial streams greatly augmented, but their activity in transporting and depositing sediment is increased many fold (plate 23). 
The advancing ice pushes against and overrides deposits previously made. It also buries and mixes with the deposits of debris the battered fragments of both bushes and trees which grew in front and on the surface of the glaciers (plates 21-23). Under the variable and everchanging conditions accompanying this deposit and overriding, there is being accumulated a remarkable deposit of stratified and unstratified material mixed with plant fragments.

\section{Possible eiconomic Effects}

In this unsettled region the economic effects of the sudden advance of the glaciers have not been of marked importance; but if the advance extends to the entire Malaspina and to the Hubbard and Turner glaciers, there may result some effects of distinct importance to man. Already the ice-cliff of Turner glacier has been extended fully a mile (plates 11 and 12) and the area of iceberg discharge thereby greatly increased. If Turner and Hubbard glaciers also push forward, the amount of ice discharged into Yakutat bay may far exceed that of the present. If Malaspina glacier advances far enough to enter Yakutat bay and the Pacific ocean, as it may possibly do, the discharge of icebergs will constitute a menace to navigation along this coast.

Farther to the northwest the town of Valdez is situated on an alluvial fan directly in front of Valdez glacier. If earthquake effects should start a wave of glacier advance there similar to that witnessed in the Yakutat Bay region, that city would be in danger both from the advancing ice and from the increased volume of water discharged from it.

In several places in Alaska trails extend over glaciers, and such an advance as that in the Yakutat Bay region would of course destroy these. In the consideration of routes for railroads, it is proposed, in some instances, to lay the tracks over or near the terminus of stagnant glaciers. Such a sudden advance of glaciers as is described above would of course completely interrupt travel along such routes. In this region of frequent earthquakes it is not at all unlikely that glaciers of other sections may during the present century receive an impulse of advance similar to that which has visited the Yakutat Bay region. It is certainly a possibility which ought to be taken into consideration in building towns, roads, and railways.

\section{ConcLusron}

In a region where the recent history of the glaciers has been almost uniformly one of recession, such a sudden advance as has been described in this paper is of interest and importance. So far as is known to the 
writer, the phenomenon is unique; and yet, if the cause assigned is the correct one, it is one which may well be expected in those mountain glacier regions that are subject to violent earthquakes. In fact, if a great shaking will cause a profound forward movement, it is probable that a lesser shaking will cause a smaller advance. It is possible that some of the observed changes in the fronts of glaciers are attributable to former earthquakes instead of climatic changes.

The beginning of the advance in this case has been witnessed, and there is every reason for believing that it will be continued, and that in the next few years other glaciers will be affected. The uniqueness and importance of the phenomenon makes it highly important that its progress and effects should be carefully studied. It will be a great pity if some means is not found by which the glaciers of this region can be carefully watched for the next few years. 
